\title{
Biogenic Selenium Nanoparticles in Animal Nutrition: A Review
}

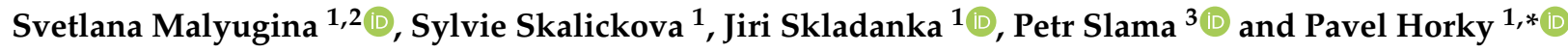 \\ 1 Department of Animal Nutrition and Forage Production, Mendel University in Brno, \\ 61300 Brno, Czech Republic; qqmalyug@mendelu.cz (S.M.); sylvie.skalickova@mendelu.cz (S.S.); \\ jiri.skladanka@mendelu.cz (J.S.) \\ 2 Agrovyzkum Rapotin Ltd., Vyzkumniku 267, 78813 Vikyrovice, Czech Republic \\ 3 Department of Animal Morphology, Physiology and Genetics, Mendel University in Brno, \\ 61300 Brno, Czech Republic; petr.slama@mendelu.cz \\ * Correspondence: pavel.horky@mendelu.cz
}

check for updates

Citation: Malyugina, S.; Skalickova, S.; Skladanka, J.; Slama, P.; Horky, P. Biogenic Selenium Nanoparticles in Animal Nutrition: A Review. Agriculture 2021, 11, 1244 https://doi.org/10.3390/ agriculture11121244

Academic Editors:

Lubomira Gresakova and Emilio Sabia

Received: 21 October 2021

Accepted: 5 December 2021

Published: 9 December 2021

Publisher's Note: MDPI stays neutral with regard to jurisdictional claims in published maps and institutional affiliations.

Copyright: (c) 2021 by the authors. Licensee MDPI, Basel, Switzerland. This article is an open access article distributed under the terms and conditions of the Creative Commons Attribution (CC BY) license (https:// creativecommons.org/licenses/by/ $4.0 /)$.

\begin{abstract}
Selenium still represents a matter of debate in the scientific community. Bionanotechnology has introduced a whole new perspective on selenium use in animal nutrition. In recent years, attention has been focused on selenium nanoparticles prepared by chemical synthesis. Societal pressure directs research in a "greenway" that is more eco-friendly. Biogenic selenium nanoparticles thus represent a new space for research in the use of this new form of selenium in animal nutrition. Recent research shows that biogenic selenium nanoparticles have low toxicity, improve antioxidant status, and increase the body's immune response. However, their benefits may be much greater, as numerous in vitro studies have shown. In addition, biogenic selenium nanoparticles possess antimicrobial, antifungal, and anticancer activities. Further research should answer questions on the use of biogenic selenium nanoparticles as a feed supplement in individual categories of livestock, and their safety in terms of long-term supplementation.
\end{abstract}

Keywords: nanoparticles; selenium; animal nutrition

\section{Introduction}

The element selenium was first described by the Swedish chemist Jöns Jacob Berzelius in 1818, who found this element in the mud at the bottom of a sulfuric acid preparation. At that time, it was believed that selenium was toxic [1]. Early research on this element was focused mainly on its toxicity as in the 1930s, it was found that selenium caused the poisoning of livestock (the so-called "alkali disease"), especially in areas with a high amount of selenium in the soil [2]. In agricultural soils, Se exists in two bioavailable inorganic forms as selenate or selenite; plants are able to uptake selenium in these two forms and convert them to organoselenium compounds such as selenocysteine (SeCys) and selenomethionine (SeMet) [3]. Plants are the main source of Se for grazing and forageeating animals such as cattle, horses, sheep, goats, and swine. Forages in which Se levels exceed $5 \mathrm{mg} / \mathrm{kg}$ should be considered hazardous for the health of livestock [4]. Some plant species are considered selenium hyperaccumulators (e.g., Astragalus spp. and Senecio spp.); they tend to easily take up selenium from the soil and accumulate it in high concentrations (1000-15,000 mg Se/kg dry matter) into their tissues [3]. Long-term ingestion of plants or fodder with contents of Se above $1 \mathrm{mg} / \mathrm{kg}$ in dry matter (DM) can cause chronic Se toxicity (i.e., selenosis) in livestock [3,5-7]. Young animals tend to be more susceptible to selenium poisoning.

Until the 1950s, selenium was considered to be toxic to humans and animals. However, perceptions of selenium significantly changed in 1957 when Schwarz and Foltz stated that the addition of Se prevented liver necrosis in rats [7]. A few years later, it was found that selenium is incorporated into leucocytes in dogs; this finding indicated the role of 
Se in immune function [8]. In 1973, scientists discovered that Se is a component of the enzyme glutathione peroxidase (GPx), which is a selenoprotein that detoxifies harmful organic hydrogen peroxides [9]. In Eukaryotes, over 26 distinct selenoproteins have been identified. However, their functions are not completely understood. All selenoproteins that are known to play a role in oxidoreductase intervening enzymes are implicated in multiple metabolic pathways, e.g., the maintenance of intracellular redox status, free radical scavenging, and repair of oxidized lipids [10]. These discoveries were the beginning of more extensive studies on the role and importance of this element for human and animal health and nutrition. Studies are still ongoing, although selenium is currently recognized as an essential micronutrient that performs multiple functions (e.g., anticancer, joint health, immune resistance, and antioxidant properties) in the growth and functioning of living animal cells and human bodies. As an element of GPx and thioredoxin reductase enzymes, selenium protects the biomolecules against reactive oxygen species (ROS) and free radical damage. Antioxidants can reduce the harmful effects of ROS on animal organisms [11]. The biological activity of Se depends on its chemical form. Selenium compounds commonly exist in four oxidation states in nature: selenate $\left(\mathrm{Se}^{+6}\right)$, selenite $\left(\mathrm{Se}^{+4}\right)$, elemental selenium $\left(\mathrm{Se}^{0}\right)$, and selenide $\left(\mathrm{Se}^{-2}\right)$. The inorganic forms of Se (i.e., selenates and selenites) are soluble in water and, usually, they present in this form in water, or they can be found in different minerals [12]. They are known to be toxic to biological systems even in low concentrations [13]. In contrast, $\mathrm{Se}^{0}$ is essentially nontoxic and highly insoluble in water; it rarely occurs in its elemental state. In the form of organic bindings, Se occurs as selenides [12], and these compounds are considered to be the most stable [14].

\section{The Importance of Selenium in Animal Nutrition}

Trace elements play an essential role in animal diet. Selenium is one of the critical nutritional factors necessary for the normal functioning of the immune system [15] and maintenance of health, growth, and various biochemical-physiological functions [16]. Numerous scientific investigations have demonstrated that a deficiency in Se could lead to serious disruptions in an animal organism such as liver necrosis, muscular dystrophy, pancreatic fibrosis, mastitis, cystic ovaries, and dysfunction of the thyroid metabolism [17-19]. The symptoms of selenium deficiency have been reported in monogastric animals and ruminants. In young ruminants, such as calves and lambs, Se (and also vitamin E) deficiency often leads to the commonly named "white muscle disease" (WMD) or nutritional muscular dystrophy [20-22]; in older ruminants, a low selenium state is associated with poor reproductive performance, unthriftiness, placental retention, and impaired immunity [18]. In monogastric animals (swine, poultry, and horses), Se deficiency leads to the damage of vital organs, such as the liver, kidney, and pancreas, and to WMD, "Mulberry heart disease" (MHD), lower immune responses, and increased susceptibility to viral infections [18,23]. Selenium deficiency can cause a variety of reproductive disorders in animals (e.g., damage of embryonic development, infertility, retained placenta in dairy cattle, abortions, and a decrease in egg production in laying hens) [24,25]. Selenium deficiency is related to oxidative stress, which refers to the production of a large amount of ROS in the body. ROS can damage cells and tissues and adversely affect organs and their functions. According to the results presented in publications in the field of human medicine, the Czech Republic was ranked among the countries with a low selenium intake, those which had populations that were found to have selenium concentrations below the European average. Thus, sufficient Se supplementation in animals tends to be important not only to maintain the good health and performance of animals themselves but also to increase its supply to the human population through higher selenium content in milk and meat. Selenium plays an important role in maintaining the good health of the mammary gland and, thus, has an impact on milk quality. Selenium deficiency is associated with increased intramammary infections in dairy cattle. When evaluating the occurrence of Se deficiency in cattle by examining the blood of 879 cows in 34 regions in the Czech Republic, selenium deficiency was found on $50 \%$ of tested animals and $54 \%$ of the farms. Studies from Slovenia and 
Ireland have reported similar findings [26,27]. Selenium deficiency is related to various Se concentrations in soils in different regions. Extensive monitoring of Se concentration in soil, plants, animal feed, and blood in 30 farms in different regions in Kosovo showed a low concentration of Se in soil (under $500 \mu \mathrm{g} / \mathrm{kg}$ ) and plants (under $50 \mu \mathrm{g} / \mathrm{kg}$ ); among all minerals measured in animals blood, the larger deficiency was found for Se [28]. Selenium deficiency in livestock is often related to low Se content in forage and pasture. Compared to the control group, calves supplemented with selenium-fortified hay had higher Se blood concentration and improved body weight and immune response upon vaccination [29]. Nordic countries (e.g., Sweden and Finland) are generally considered to be selenium-poor areas $(<0.125 \mathrm{mg} / \mathrm{kg})$ [30-32]. Currently, almost all crop fertilizers in Finland contain Se in the chemical form of sodium selenate $(15 \mathrm{mg} \mathrm{Se} / \mathrm{kg})$. In areas such as China and North America, where irrigated soils contained excessive Se concentrations $(>1 \mathrm{mg} / \mathrm{kg})$, it led to high Se concentrations in surface waters, causing the phenomena of Se pollution, ecological damage, and human diseases [33]. Possible toxic effects for humans and animals as a result of the excessive Se contention in water may be a future challenge. Currently, there is no regulation concerning Se supplementation in animals; however, the National Research Council (NRC) provides guidance. The daily dietary requirements of Se in cattle recommended by NRC are $100 \mu \mathrm{g} / \mathrm{kg}$ of DM for beef cattle and calves, and $300 \mu \mathrm{g} / \mathrm{kg}$ DM per day for dairy cows [34]. Poultry Se requirements range between 150 and $200 \mu \mathrm{g} / \mathrm{kg}$ DM; some diets also include $300 \mu \mathrm{g} / \mathrm{kg}$ DM [35] (Table 1). Current regulations in the US allow up to $300 \mu \mathrm{g} / \mathrm{kg}$ DM of dietary addition of Se in poultry diet, and for the European Union, the total maximal level of dietary Se inclusion is up to $500 \mu \mathrm{g} / \mathrm{kg}$ DM [36]. The dietary Se requirements for swine ranges from $150 \mu \mathrm{g} / \mathrm{kg}$ DM for finishing pigs and sows to $300 \mu \mathrm{g} / \mathrm{kg}$ DM for weaning pigs [37]. Even though selenium is important for many physiological functions in the body, a high dietary level of Se can cause toxicity. Doses of Se which cause acute toxicity in different animal species are represented in Table 2. Signs of acute Se toxicity may vary with the concrete amount of Se consumption or administration, the chemical form of Se, animal age, and species [38], but they usually follow death within 2-5 h after acutely toxic Se consumption or injection of Se [39]. Selenium can be found in all agroecosystems, such as soils, rocks, and water. Acute oral selenium poisoning usually occurs with exposure ranging from 1 to $10 \mathrm{mg} / \mathrm{kg}$ bw depending on the species (Table 1), age, and Se chemical form. Young animals are more susceptible to acute Se toxicosis with dosages of $0.2-0.5 \mathrm{mg} / \mathrm{kg}$ bw. Parenteral Se products can cause acute toxicity and death at dosages of $1 \mathrm{mg} / \mathrm{kg}$ bw [39].

Table 1. Selenium daily nutritional requirement (supranutritional) and acute toxic levels in various animal species.

\begin{tabular}{cccc}
\hline Animal Species & $\begin{array}{c}\text { Selenium Daily Nutritional } \\
\text { Requirement }(\boldsymbol{\mu g} / \mathbf{k g} \mathbf{D M})\end{array}$ & $\begin{array}{c}\text { Se Dose }(\mathbf{m g} / \mathbf{k g} \text { Body Weight-BW) } \\
\text { Inducing Acute Toxicity }\end{array}$ & Reference \\
\hline Dairy cattle & 300 & 3.0 & {$[34]$} \\
Beef cattle & 100 & 3.0 & {$[34]$} \\
Sheep, goat & $100-300$ & 0.5 & {$[40,41]$} \\
Swine & $150-300$ & 3.2 & {$[37]$} \\
Horse & $100-200$ & 3.0 & {$[42]$} \\
\hline
\end{tabular}

Table 2. List of dietary selenium sources in animal nutrition.

\begin{tabular}{cl}
\hline Selenium Sources & \multicolumn{1}{c}{ Description } \\
\hline Inorganic & Reference \\
& - $\quad$ Relatively nontoxic; \\
& Cower bioavailability in comparison with organic Se and SeNPs; \\
& Inorganic Se salts are frequently used as feed supplements because they are cost effective \\
& and relatively nontoxic; they are most commonly supplemented in the form of injections \\
or mineral-salt complexes. However, they were reported to have lower bioavailability \\
and lower transfer to animal products compared to organic Se and SeNPs.
\end{tabular}


Table 2. Cont.

\begin{tabular}{|c|c|c|}
\hline Selenium Sources & Description & Reference \\
\hline Organic & $\begin{array}{l}\text { - Naturally derived by plants; occurs in feeds; } \\
\text { - } \quad \text { Better bioavailability in comparison with inorganic Se; } \\
\text { - } \quad \text { Coss toxic than inorganic Se; } \\
\text { - } \quad \text { Absorbed by active transport in the intestinal tract. }\end{array}$ & {$[44,45]$} \\
\hline $\begin{array}{l}\text { Selenomethionine (SeMet); } \\
\text { Selenocysteine (SeCys) }\end{array}$ & $\begin{array}{l}\text { SeMet is often supplemented in the form of SYs. Organic Se sources have shown better } \\
\text { bioavailability and improved Se storage in animal tissues compared to inorganic. }\end{array}$ & \\
\hline Selenium nanoforms & $\begin{array}{l}\text { - } \quad \text { Prepared via } 3 \text { different routes: chemical, physical, and biological; } \\
\text { - } \quad \text { High Bioavailability; } \\
\text { - } \quad \text { Less toxic compared to inorganic and organic Se; } \\
\text { - } \quad \text { Mechanism of absorption and distribution in tissues is not totally known. }\end{array}$ & {$[46-48]$} \\
\hline $\begin{array}{l}\text { SeNPs prepared using a } \\
\text { chemical/physical method; } \\
\text { biogenic SeNPs prepared via green } \\
\text { synthesis }\end{array}$ & $\begin{array}{l}\text { Chemically synthesized SeNPs are less toxic to animals than inorganic and organic Se } \\
\text { sources, but they are not environmentally friendly due to the toxic chemicals produced } \\
\text { during the NPs' preparation. Biogenic NPs are more stable, more eco-friendly, and less } \\
\text { toxic. }\end{array}$ & \\
\hline
\end{tabular}

\section{Selenium Supplementation}

Selenium can affect the immune and antioxidant systems of animals through GPx and selenoproteins with various biological functions. Dietary Se can be supplemented in animals from two important sources: organic and inorganic. Organic Se is more bioavailable than inorganic Se [Table 2]. In recent years, the application of Se in nanoforms (Table 2) has attracted more attention, mainly due to the possibility of using Se in a zero-oxidation state $\left(\mathrm{Se}^{0}\right)$, which presents low toxicity and better bioavailability compared to other oxidation states [49]. Moreover, supplementation of NPs can improve the delivery and absorption of the trace elements in animals and humans while causing no environmental damage.

\subsection{Selenium Absorption and Bioavailability}

The efficiency of Se absorption is affected by the form of dietary selenium and differs between ruminants and non-ruminants [50]. It has been found that organic forms of Se are actively absorbed in the intestinal tract via an amino acid transport mechanism, unlike inorganic Se, which is absorbed by a simple diffusion process [51]. Selenomethionine (SeMet) is essential for humans and animals and cannot be synthesized in the body [52]. Selenocysteine (SeCys) is a structural component (cofactor) of selenoenzymes; therefore, it is important for their catalytic activity. These selenoenzymes play a key role in redox homeostasis in mammals; their active component is SeCys which is synthesized in the body de novo [53]. GPx and other selenoenzymes are the major Se-containing antioxidants in the body that help to neutralize ROS [54]. The expression of selenoproteins is specific to various tissues and depends on Se availability in feed [55]. Selenoproteins help animals resist oxidative stress, which can be caused by, heat, decreased productive performance, and various diseases (e.g., mastitis and intramammary infections in dairy cattle). The concentration of GPx is typically analyzed in blood plasma to assess selenium deficiency and to evaluate antioxidant status or oxidative stress [56]. In the case of Se deficiency, GPx concentration tends to be low. When oxidative stress is high and Se contention in feed is limited, L-SeMet is released from the proteins due to the protein turnover and provides Se for the production of selenoproteins. SeCys, the same as inorganic Se, does not play a significant role as a nutritious Se source [57]. SeMet represents the storage form of Se in animal and human tissues [58]. Dietary selenomethionine can be incorporated into muscle protein in place of methionine and become a rich store of selenium; it represents a highly available substrate for many proteins and can substitute methionine in the protein structure [58,59]. All dietary Se sources, except for organic L-SeMet present in SYs or naturally derived in plants, are primarily metabolically transformed to selenide in the liver and then used for SeCys synthesis. Non-ruminant animals are not able to 
synthesize selenomethionine from inorganic forms of selenium [60] but can convert it to another essential amino acid-selenocysteine [16]. The mineral (inorganic) forms of Se are reported to have some disadvantages such as relatively high toxicity, low transfer to animal products (milk, eggs, and meat), and the inability to facilitate Se storage in the body [16,61]. In ruminants, microbial digestion by ruminal microorganisms (RMOs) proceeds before digestion in the abomasum and small intestine [62]. The ruminal microbes reduce most of supplemented inorganic Se to unabsorbable selenium sources (selenide and elemental selenium), thereby decreasing Se bioavailability to 20-25\% [51]. The absorption of inorganic Se in the form of sodium selenite in the small intestines of monogastric animals and poultry is approximately $80 \%$, while in ruminants, this range is only $29 \%$, and for organic Se in monogastric species and poultry, it is greater than $90 \%[19,63]$. This difference appears to be the result of as reduction in dietary Se forms by microbes in the rumen. The organic forms of selenium naturally occur in plant-based feedstuffs, and selenized yeast (SY) are selenoaminoacids (selenomethionine and selenocysteine), which contain a selenol group in place of the sulfur-containing thiol group [18]. SeMet is considered a metabolically effective organic Se and is traditionally supplemented in the form of selenized yeast (SY), which has been grown in a high selenium medium. In animals' intestinal tracts, proteins from SYs are broken down into small peptides and then amino acids. Thus, SeMet can be absorbed in the intestine the same way as amino acid methionine and build selenium deposition in the body. However, the binding of selenium by microbial cells highly depends on the concentration of Se in the cultivation medium and cultivation conditions [64]. Selenium can be found in all cells and tissues, but the level of Se and its distribution in the body tissues is influenced by the dietary Se form and intake. After oral selenium supplementation (organic SY and inorganic sodium selenite), the Se uptake in sheep was only $34 \%$, whereas, in pigs, it was 85\% [51]. Some studies demonstrated increased Se concentrations in meat after SY dietary inclusion compared to inorganic Se $[65,66]$. In their study, Paiva et al. [66] demonstrated the increase in muscle Se in lambs supplemented with organic Se $(0.2,0.4$, and $0.8 \mathrm{mg} / \mathrm{kg} \mathrm{DM})$ compared to the inorganic Se form. Selenium content in the muscle was higher with more Se inclusion in the diet linearly. Organic Se sources demonstrated a higher capacity to accumulate Se in muscles than inorganic Se. Hepatic GPx activity was found to be higher in animals supplemented with sodium selenite (SS), which refers to the metabolic pathway of inorganic Se. Sodium selenite biotransformed to selenide for further GPx synthesis more quickly. Similar results were obtained by Steen et al. [67]. Se concentrations in the muscles and blood of lambs receiving organic Se were significantly higher compared to the inorganic group. Improved beef meat quality parameters (e.g., color stability) and increased Se concentration in the muscles of Charolais bulls supplemented with organic Se $(0.2 \mathrm{mg} / \mathrm{kg} \mathrm{DM})$ for 60 days were observed by Grossi et al. [57]. The selenium concentration in the meat of Nellore cattle was higher in animals supplemented with organic Se (0.3, 0.9, and $2.7 \mathrm{mg} / \mathrm{kg}$ DM) compared to organic Se [68]. Results obtained by Hall et al. [69] and Galbraith et al. [70] also showed better bioavailability of the organic forms of Se compared to the inorganic form. An increase in Se in the blood serum and GPx activity in lambs was demonstrated after organic and inorganic Se $(0.15 \mathrm{mg} / \mathrm{kg} \mathrm{DM})$ supplementation; no significant difference between the organic and inorganic Se forms was observed [71]. Various species of ruminant animals (i.e., dairy cows, beef cattle, calves, and lambs) were supplemented with the ten times maximum permitted Se (in the organic form of SY) dosage of $0.568 \mathrm{mg} / \mathrm{kg} \mathrm{DM}$, and there was no adverse health effect observed. Moreover, it was observed to increase Se in the blood and milk samples [72]. The digestive system of animals is more adapted to the organic form of Se, which naturally occurs in feeds, and it has better assimilation [73]. Organic Se in high doses can also be toxic, but SeMet does not produce free radicals when reacting with glutathione. However, the molecular mechanism of selenium toxicosis is not well understood and indeed needs further investigation. Selenium supplementation (SY and SS at the dose $0.4 \mathrm{mg} / \mathrm{kg} \mathrm{DM}$ ) increased GPx activity, regardless of the selenium source [74]. Some other studies also did not confirm the greater biological effects of organic Se [75-77]. 
Postpartum and pregnant animals are generally more susceptible to Se deficiency and often require Se supplementation due to oxidative stress, which can be caused by pregnancy itself. Dietary organic Se supplementation in postpartum mice enhanced Se deposition in the liver, blood, and mammary gland, in addition to an increase in GPx activity [78]. In dairy cattle, oxidative stress during pregnancy and postpartum can increase intramammary diseases and mastitis cases. Long-term Se deficiency may also lead to thyroid-related diseases such as autoimmune thyroiditis [25]. Se supplementation in pregnant and lactating ewes showed a significant increase in the Se concentration in the blood and an increase in thyroid hormones compared to the control group [79]. These results suggest that organic Se supplementation can improve the antioxidant status of pregnant animals. More efficient transfer of Se from organic Se dietary sources to dairy cattle milk in comparison with inorganic Se was demonstrated [80-82]. Due to the fact of these controversial results, additional investigations in this research area are strongly recommended.

Many studies have described the bioavailability of different chemical forms of selenium $[51,56,63,64]$, e.g., diets enriched with the organic Se increased Se concentrations in animal tissues compared to animals supplemented with inorganic Se.

The selenium-enriched microalgae, Chlorella vulgaris, was used as an organic source of dietary Se $[83,84]$. The effects of the supplementation of sodium selenite and selenized microalgae biomass on fish mortality, growth, and the accumulation of Se in the muscles and liver were observed in common barbel [83]. The results showed more accumulation and bioavailability of Se in muscles and liver in barbel supplemented with Se-enriched microalgae than animals supplemented with inorganic sodium selenite. Marounek et al. [85] also observed better accumulation of Se in tissues of rabbits supplemented with organic Se yeasts and Se microalgae. Similar results were obtained by Hassan et al. [86,87]. Reports on the concentration of SeMet in Chlorella vulgaris are controversial. De Alcantara et al. [88] found that $70 \%$ of intracellular Se in Chlorella vulgaris is in the form SeMet.

In contrast, Neuman et al. [89] found 24-30\% of SeMet from the total amount Se accumulated in algae cells, but the concentration of SeCys in algae cells was higher (48.76\%). Supplementation in animals with Se-enriched microalgae can benefit from the presence of antioxidants, vitamins, and other biologically active compounds. On the other hand, microalgae cultivation is costly, and the accumulation of intracellular SeMet can be various depending on the cultivation method and conditions.

\subsection{Selenium and Vitamin $E$}

The most studied beneficial health effect of Se has been studied in connection with vitamin E. Vitamin E and Se have interrelated functions in animals and human organisms. Inadequate amounts in the diet leads to similar adverse effects. The synergetic interaction between Se and vitamin E can enhance GPx synthesis, an important part of the antioxidant pathway in the body. Selenium deficiency is often characterized by low concentrations of both Se and vitamin E [90]. Thus, optimum Se and vitamin E levels are necessary to minimize the oxidative damage of cells and tissues in the body [12]. Supplementing dairy cows with low doses of both vitamin E and Se (Se injection $1 \mathrm{mg} / \mathrm{kg} \mathrm{bw}$; vitamin E $32 \mathrm{~g} / \mathrm{d}$ ) reduced the duration of clinical mastitis symptoms by $62 \%$, in cows supplemented only with vitamin E mastitis, the duration of symptoms was reduced by $44 \%$, and in cows supplemented with Se by $46 \%$ [91]. These results demonstrate the beneficial interaction of Se-vitamin E (SeE) dietary inclusion in reducing the duration of clinical mastitis, which can improve dairy cows' production. Zahrazadeh et al. [92] evaluated the influence of SeE injection ( $0.5 \mathrm{mg}$ of Se in the form of sodium selenite; $56 \mathrm{IU}$ of vitamin E) on body condition, lactation performance, and oxidative status in dairy cows. SeE injections showed a beneficial effect on body score, antioxidative parameters, and lactating performance in Holstein cows. The mechanism of the beneficial effect of vitamin E and SeE supplementation on mastitis is not fully understood, and this needs further research. Hogan et al. [93] observed that vitamin E deficiency was associated with a reduction in neutrophils that had 
bactericidal activity and increased mastitis. Ali et al. [94] reported that SeE injections (75 mg of vitamin E per day per animal; $2800 \mathrm{mg}$ of Se) improved the reproductive performance of lambs compared to vitamin E supplementation alone. In another study, Se supplemented alone had a better effect on the semen quality of boars than the group supplemented with SeE [95]. Kappel et al. [96] did not observe the improvement in reproductive efficacy in cows injected with SeE (680 IU of vitamin E and $50 \mathrm{mg}$ of Se in the form of sodium selenite). The daily nutritional requirement of vitamin $\mathrm{E}$ for adult cattle recommended by the National Research Council (NRC) is 15-60 international units (IUs). The daily nutritional need for nursing calves ranges between 40 and 60 IUs [34]. Supplementation of $0.3 \mathrm{mg} / \mathrm{kg}$ bw of organic Se and $100 \mathrm{mg} / \mathrm{kg}$ of vitamin E improved the immune status of broiler chickens, but there was no difference found compared to the animal group supplemented with Se alone [97]. In recent years, only a few studies have been related to the toxic effects of vitamin E supplementation. In general, vitamin $\mathrm{E}$ is considered to be one of the least toxic of the vitamins [37]. A study on higher doses (500, 1000, and $2000 \mathrm{mg} / \mathrm{kg} \mathrm{bw}$ ) of vitamin $\mathrm{E}$ oral supplementation over 30 days in albino rats showed a negative effect on the liver and kidneys. Still, no deaths were recorded [98]. Hale et al. [99] reported on the toxicity of intravenous vitamin $\mathrm{E}(33.5 \mathrm{mg} / \mathrm{kg} \mathrm{bw})$ supplementation in neonatal piglets. Rapid intravenous injections of vitamin $\mathrm{E}$ resulted in sepsis and abnormal pulmonary function. Further studies are needed to investigate the possible undesirable effect of vitamin $\mathrm{E}$ supplementation and to determine appropriate dosage levels.

\section{Selenium Nanoparticles in Animal Nutrition}

An appropriate animal diet and living environment play a key role in animal health and performance. Thus, optimizing these factors is important for increasing rearing efficiency, which can positively determine the quality of production of animal origin. Over the last decade, nanotechnology has received the attention of many researchers due to its promising agricultural and food applications. Nanotechnology provides new "intelligent" solutions in animal nutrient delivery and health protection, and, indeed, it has the large potential to improve animal production systems [100]. This interest is mainly caused by the unique physicochemical properties of nanoparticles (NPs), which refers to their small size (1-100 nm), high stability, hydrophobicity, and large surface area. NPs' hydrophobicity is important for good dispersion in water or serum and is also required to enhance their interaction with cell membranes [101]. The NPs' size affects the cellular intake and allows them to easily pass through the stomach wall and diffuse into body cells quicker than common elements with larger particle sizes. The in vitro absorption of NPs with a diameter of $0.1 \mu \mathrm{m}$ was found to be higher than 1 and $10 \mu \mathrm{m}$ NPs [102]. The thickness of gastric mucus layers (total mucus), which continuously cover the gastrointestinal tract's (GIT) surface, varies from $200 \mu \mathrm{m}$ in the small intestine to $480-800 \mu \mathrm{m}$ in the large intestine [14] and could allow the transport of NPs through the layer. According to Corbo et al. [103], NPs, especially nanominerals (e.g., Se and Zn), have a higher surface-area-to-volume ratio, providing more surface area for contact with the mucosal tissues and cells. Better absorption of NPs into the mucosal surface increases the particle residence time in the GIT. When a nanomineral is introduced into a biological medium, such as blood or mucus, proteins adsorb on its surface, giving it a unique "biological identity", a so-called protein corona, which can have an impact on the NPs' distribution as well as their potential toxicity [104]. Nanoparticles have been used in animal nutrition for their antibacterial, antifungal, and antioxidant properties as well as probiotics and to maintain general animal performance and health. The antimicrobial activities of metallic NPs (e.g., $\mathrm{ZnO}, \mathrm{CuO}$, and AgNPs) and SeNPs have been demonstrated by different researchers [105-108].

Selenium nanoparticles (SeNPs) are nano-sized (generally $<60 \mathrm{~nm}$ in diameter) elemental selenium particles with excellent nano-properties [109]. For the NPs' synthesis, there are two main strategies used: bottom-up (including chemical vapor deposition, hydrothermal and solvothermal methods, chemical reduction, and green synthesis) and top-down (including mechanical milling, laser ablation, etching, sputtering, and electro- 
explosion). The top-down strategy involves the mechanical breaking down of the bulk material into nanostructured materials. In contrast, the bottom-up method uses chemical reactions to break bulk into several parts to form NPs [110]. Methods of NPs synthesis can also be divided into physical, chemical, and biological (the so-called "green way" or "green synthesis"). The chemical methods of nanoparticle synthesis are the most common approaches commercially employed in various areas of NP applications. Concurrently, plenty of research indicates a potential environmental threat of nanotechnology related to NP toxicity [111-115]. The chemical approach to NP synthesis is related to the use of toxic chemicals, which are hazardous to humans and the environment [116]. Designing NPs via a green route using biological and eco-friendly materials reduces the negative environmental impact [117].

Various studies have investigated the possibilities of using selenium nanoparticles as a new source of selenium (Table 3). For instance, sodium selenite NPs coated with methacrylate polymers were orally supplemented with ruminants, improving selenium absorption [62]. Shi et al. [118] stated that dietary nano-sized Se improved Se content in the blood and tissues and enhanced ruminal fermentation and feed utilization in sheep, which were fed a basal diet supplemented with $0.3,3$, and $6 \mathrm{~g} / \mathrm{kg}$ DM of nano-Se. Kojouri et al. [119] reported the positive effect of dietary SeNPs inclusion $(0.1 \mathrm{mg} / \mathrm{kg}$ DM for 60 days) on the antioxidant activity and weight gain of young lambs. In another experiment, the inclusion of $1 \mathrm{mg} / \mathrm{kg}$ DM of nano-sized Se into sheep's diet exhibited a better antioxidative effect after 20-30 days of supplementation [120]. Xun et al. [121] also reported enhanced rumen fermentation and feed conversion efficiency in sheep supplemented with $4 \mathrm{mg} / \mathrm{kg}$ DM of nano-sized Se compared with selenium yeast (SY). In another experiment, supplementation with $0.5 \mathrm{mg} / \mathrm{kg}$ DM of nano-sized Se improved hair follicle development and promoted growth in Cashmere goats [122]. Experiments with nano-Se inclusion in broiler chicken diets conducted by Gangadoo et al. [48,123] demonstrated improved gut health and general animal performance; the best results in both experiments were obtained with an SeNP supplementation of $0.9 \mathrm{mg} / \mathrm{kg}$ DM with no toxic effect occurring. Previous studies have demonstrated the benefits of using SeNPs in broiler feed, with increased absorption and diffusion of material into organs and tissues, increased antioxidant capacity, and meat quality.

In contrast, Wang et al. [124] did not observe any beneficial effect of SeNP supplementation in terms of enhancing the oxidative status in broilers, but Se improved the survival rates. Gulyas et al. [125] reported changes in the proteome profile in chickens after SeNPs supplementation. These results could be related to the specific patented method of NP preparation used in this study. Several studies reported improvements in the growth performance [126-128], intestinal health [129,130], and antioxidant status [131] of aquatic animals supplemented with SeNPs. Se supplementation alleviated the antioxidant balance and enhanced kidneys cells' resistance to oxidative damage in grass carp [132]. In another study, SeNP supplementation improved intestinal health, feed utilization, and growth performance in Nile tilapia [130]. The enhancement of the growth performance and feed efficiency after SeNP supplementation $(0.4-0.8 \mathrm{mg}$ ) in Nile tilapia was also observed by Ibrahim et al. [133]. Markedly, the nanoform of Se can enhance growth performance in fish. The recommended dosage of SeNP dietary inclusion ranges from 0.15 to $4 \mathrm{mg} / \mathrm{kg}$ depending on the fish species [134].

Table 3. Effect of SeNP supplementation on animal health and performance.

\begin{tabular}{ccccc}
\hline $\begin{array}{c}\text { Experimental } \\
\text { Animals }\end{array}$ & Element & Dose & Toxicity & Major Effect \\
\hline Dorset sheep & SeNPs & $\begin{array}{l}\text { 0.3,3, and } 6 \mathrm{mg} / \mathrm{kg} \\
\text { DM fed for } 75 \text { days }\end{array}$ & No information & $\begin{array}{l}\text { Improved Se content in blood and } \\
\text { tissues and enhanced ruminal } \\
\text { fermentation and feed utilization }\end{array}$ \\
\hline $\begin{array}{c}\text { Small tail Han } \\
\text { sheep }\end{array}$ & SeNPs & $\begin{array}{l}0.3,3, \text { and } 6 \mathrm{mg} / \mathrm{kg} \\
\text { DM fed for } 75 \text { days }\end{array}$ & No information & $\begin{array}{l}\text { Improved Se content in blood and } \\
\text { tissues and enhanced ruminal } \\
\text { fermentation and feed utilization }\end{array}$ \\
\hline
\end{tabular}


Table 3. Cont

\begin{tabular}{|c|c|c|c|c|c|}
\hline $\begin{array}{l}\text { Experimental } \\
\text { Animals }\end{array}$ & Element & Dose & Toxicity & Major Effect & Reference \\
\hline Tan sheep & SeNPs & $\begin{array}{l}0.3,3 \text {, and } 6 \mathrm{mg} / \mathrm{kg} \\
\mathrm{DM} \text { fed for } 75 \text { days }\end{array}$ & No information & $\begin{array}{l}\text { Improved Se content in blood and } \\
\text { tissues and enhanced ruminal } \\
\text { fermentation and feed utilization }\end{array}$ & [118] \\
\hline Neonatal lambs & Sans & $\begin{array}{l}0.1 \mathrm{mg} / \mathrm{kg} \mathrm{DM} \text { fed } \\
\text { for } 60 \text { days }\end{array}$ & No information & $\begin{array}{l}\text { Improved weight gain on the 14th and } \\
\text { 28th day; enhanced antioxidant } \\
\text { parameters }\end{array}$ & [119] \\
\hline $\begin{array}{l}\text { Lori-Bakhtiari } \\
\text { sheep }\end{array}$ & SeNPs & $\begin{array}{l}1 \mathrm{mg} / \mathrm{kg} \text { DM diet for } \\
10 \text { days }\end{array}$ & $\begin{array}{l}\text { SeNPs were found to be } \\
\text { less toxic than SS }\end{array}$ & $\begin{array}{l}\text { Improved antioxidant parameters } \\
\text { compared to the experimental group } \\
\text { fed with sodium selenite (SS) }\end{array}$ & [120] \\
\hline Sheep & SeNPs & $4 \mathrm{mg} / \mathrm{kg} \mathrm{DM}$ & No information & $\begin{array}{l}\text { Enhanced rumen fermentation and } \\
\text { feed conversion efficiency compared } \\
\text { with the group fed with } 4 \mathrm{mg} / \mathrm{kg} \text { DM } \\
\text { selenized yeast (SY) }\end{array}$ & [121] \\
\hline Cashmere goats & SeNPs & $0.5 \mathrm{mg} / \mathrm{kg} \mathrm{DM}$ & No information & $\begin{array}{l}\text { Improved the hair follicle } \\
\text { development and promoted growth }\end{array}$ & [122] \\
\hline Khalkhali goats & SeNPs & $\begin{array}{l}0.5 \text { mg per animal } \\
\text { per day }\end{array}$ & No information & $\begin{array}{l}\text { SeNP inclusion improved Se status in } \\
\text { goats (increased Se in blood, } \\
\text { colostrum, and milk) compared to SS } \\
\text { and SeMet }\end{array}$ & [82] \\
\hline Makuei sheep & SeNPs & $\begin{array}{c}0.1 \mathrm{mg} / \mathrm{kg} \text { of live } \\
\text { weight }\end{array}$ & No information & $\begin{array}{l}\text { Reduced oxidative stress and } \\
\text { enhanced weight gain compared to } \\
\text { the group supplemented with SS }\end{array}$ & [135] \\
\hline Male rats & SeNPs & $\begin{array}{l}0.5,1.5,3.0, \text { and } \\
5.0 \mathrm{mg} \mathrm{Se} / \mathrm{kg} \text { for } \\
28 \text { days }\end{array}$ & $\begin{array}{l}\text { Damage of the liver } \\
\text { parenchyma and intestinal } \\
\text { epithelium in animal } \\
\text { groups fed with } 1.5,3 \text {, and } \\
5 \mathrm{mg} \mathrm{Se} / \mathrm{kg}\end{array}$ & $\begin{array}{l}\text { Increased Se content in the blood } \\
\text { compared to the control group }\end{array}$ & [136] \\
\hline Mice & SeNPs & $\begin{array}{l}4,40, \text { and } 400 \mu \mathrm{g} / \mathrm{kg} \\
\text { of bw }\end{array}$ & $\begin{array}{l}\text { Dietary SeNPs showed less } \\
\text { toxicity compared to } \\
\text { inorganic SS and sodium } \\
\text { hydroselenite but was more } \\
\text { toxic than SY; subacute } \\
\text { toxicity was observed with } \\
\text { administration } \\
\text { of } 400 \mu \mathrm{g} / \mathrm{kg} \mathrm{bw}\end{array}$ & $\begin{array}{l}\text { Inorganic Se forms showed higher } \\
\text { toxicity in comparison with SeNPs } \\
\text { and organic SY }\end{array}$ & [137] \\
\hline Swiss albino mice & SeNPs & $\begin{array}{l}2 \mathrm{mg} / \mathrm{kg} \text { of bw was } \\
\text { administrated }\end{array}$ & $\begin{array}{l}\text { Organic and inorganic Se } \\
\text { forms showed less toxicity } \\
\text { at the same dosage of } \\
2 \mathrm{mg} / \mathrm{kg} \text { of bw }\end{array}$ & $\begin{array}{l}\text { SeNPs improved antioxidant } \\
\text { protection of cells compared to } \\
\text { inorganic forms }\end{array}$ & [47] \\
\hline Male rats & SeNPs & $\begin{array}{c}0.0,0.2,0.4,0.8,2.0 \\
4.0, \text { or } 8.0 \mathrm{mg} \mathrm{Se} / \mathrm{kg} \\
\text { of bw were } \\
\text { administrated for } \\
14 \text { consecutive days }\end{array}$ & $\begin{array}{l}\text { Doses greater than } 2.0 \mathrm{mg} \\
\mathrm{Se} / \mathrm{kg} \text { of bw induced } \\
\text { chronic toxicity }\end{array}$ & $\begin{array}{l}\text { Supranutritional levels }(0.2,0.4 \text {, and } \\
0.8) \text { of SeNPs did not show toxic effect }\end{array}$ & [138] \\
\hline $\begin{array}{l}\text { Male } \\
\text { Sprague-Dawley } \\
\text { (SD) rats }\end{array}$ & SeNPs & $\begin{array}{c}0.0,0.2,0.4,0.8,2.0 \\
4.0, \text { or } 8.0 \mathrm{mg} \mathrm{Se} / \mathrm{kg} \\
\text { of bw were } \\
\text { administrated for } \\
2 \text { weeks }\end{array}$ & $\begin{array}{c}\text { Doses greater than } 4.0 \mathrm{mg} \\
\text { Se } / \mathrm{kg} \text { of bw induced } \\
\text { chronic toxicity, damaging } \\
\text { effect }\end{array}$ & $\begin{array}{l}\text { Supranutritional levels }(0.2,0.4 \text {, and } \\
0.8) \text { of SeNPs had a positive effect on } \\
\text { reproductive function (promoted } \\
\text { sperm motility) }\end{array}$ & [139] \\
\hline Male SD rats & SeNPs & $\begin{array}{l}0.0,0.2,0.4, \text { or } 0.8 \mathrm{mg} \\
\mathrm{Se} / \mathrm{kg} \text { of bw were } \\
\text { administrated for } \\
2 \text { weeks }\end{array}$ & $\begin{array}{c}\text { No toxic effect was } \\
\text { observed }\end{array}$ & $\begin{array}{l}\text { Improved antioxidant capacity in the } \\
\text { liver and kidney; beneficial effects on } \\
\text { immune and antioxidant capacity } \\
\text { (dose of } 0.4 \mathrm{mg} \text { had the best response) }\end{array}$ & [140] \\
\hline $\begin{array}{l}\text { Male SD rats, } \\
\text { Buffalo rats }\end{array}$ & SeNPs & $\begin{array}{l}0.0,2,4 \text {, or } 8 \mathrm{mg} \\
\text { Se } / \mathrm{kg} \text { of bw were } \\
\text { administrated for } \\
2 \text { weeks }\end{array}$ & $\begin{array}{l}\text { SeNP administration over } \\
4.0 \mathrm{mg} \mathrm{Se} / \mathrm{kg} \text { bw caused a } \\
\text { toxic effect on liver }\end{array}$ & $\begin{array}{l}\text { Impaired the antioxidant capacity in } \\
\text { serum with the administration of } \\
\text { non-lethal doses }\end{array}$ & [141] \\
\hline $\begin{array}{l}\text { Female and male } \\
\text { rats }\end{array}$ & $\begin{array}{l}\text { SeNPs } \\
(20 \mathrm{~nm})\end{array}$ & $\begin{array}{l}0.05,0.5, \text { or } 4 \mathrm{mg} \\
\mathrm{Se} / \mathrm{kg} \text { bw } / \text { day for } \\
28 \text { days for female } \\
\text { rats; } 4 \mathrm{mg} \text { Se } / \mathrm{kg} \\
\text { bw } / \text { day for male rats }\end{array}$ & $\begin{array}{l}\text { Nanoparticle-specific } \\
\text { toxicity of Se did not occur; } \\
\text { no histological changes in } \\
\text { the liver occurred }\end{array}$ & $\begin{array}{l}\text { Lowered body weight at all doses of } \\
\text { SeNPs }\end{array}$ & [142] \\
\hline
\end{tabular}


Table 3. Cont.

\begin{tabular}{|c|c|c|c|c|c|}
\hline $\begin{array}{l}\text { Experimental } \\
\text { Animals }\end{array}$ & Element & Dose & Toxicity & Major Effect & Reference \\
\hline Male rats & SeNPs & $\begin{array}{c}0.5,1.5,3.0, \text { and } \\
5.0 \mathrm{mg} \mathrm{Se} / \mathrm{kg} \text { were } \\
\text { administered for } 28 \text { days }\end{array}$ & $\begin{array}{l}\text { Tested doses did not have } \\
\text { a significant toxic effect } \\
\text { on liver, kidney, or spleen }\end{array}$ & $\begin{array}{l}\text { Enhanced Se content in blood } \\
\text { compared to the control group }\end{array}$ & [143] \\
\hline Mice & $\begin{array}{l}\text { Biogenic SeNPs } \\
50-80 \mathrm{~nm} \\
\text { synthesized } \\
\text { using } \\
\text { Lactobacillus casei }\end{array}$ & - & No toxic effect occurred & $\begin{array}{l}\text { Protected the intestinal barrier } \\
\text { function against oxidative } \\
\text { damage }\end{array}$ & [144] \\
\hline Male mice & $\begin{array}{l}\text { Biogenic SeNps } \\
80-220 \mathrm{~nm} \\
\text { synthesized } \\
\text { using Bacillus sp. } \\
\quad \text { MSh-1 }\end{array}$ & $\begin{array}{c}\text { oral administration of } 0 \\
2.5,510 \text {, and } 20 \mathrm{mg} \mathrm{kg}^{-1} \\
\text { of Se NPs for } \\
14 \text { consecutive days }\end{array}$ & $\begin{array}{l}\text { A dose of } 20 \mathrm{mg} / \mathrm{kg} \\
\text { showed toxicity }\end{array}$ & $\begin{array}{l}\text { Less toxic effect compared to } \\
\text { synthetic SeNPs }\end{array}$ & [107] \\
\hline Male mice & $\begin{array}{l}\text { Biogenic SeNPs } \\
\text { produced using } \\
\text { yeast strain } \\
\text { Kluyveromyces } \\
\text { lactis GG799 }\end{array}$ & $0.2,0.6$, and $6 \mathrm{mg} / \mathrm{kg}$ & No toxic effect occurred & $\begin{array}{l}\text { Attenuation of oxidative stress, } \\
\text { intestinal inflammation, and } \\
\text { intestinal barrier disfunction }\end{array}$ & [145] \\
\hline $\begin{array}{l}\text { Ross } 308 \text { broiler } \\
\text { male chicken }\end{array}$ & SeNPs & $\begin{array}{l}0.3,0.9 \text {, and } 1.5 \mathrm{mg} \mathrm{Se} / \mathrm{kg} \\
\text { were fed for } 28 \text { days }\end{array}$ & $\begin{array}{l}\text { No toxic effect in tissues } \\
\text { occurred }\end{array}$ & $\begin{array}{l}\text { Improved the gut microflora } \\
\text { environment; the best } \\
\text { performance demonstrated a } \\
0.9 \mathrm{mg} / \mathrm{kg} \text { Se concentration }\end{array}$ & [123] \\
\hline $\begin{array}{l}\text { Broiler male } \\
\text { chicken }\end{array}$ & SeNPs & $\begin{array}{l}0.3,0.9 \text {, and } 1.5 \mathrm{mg} \mathrm{Se} / \mathrm{kg} \\
\text { were fed for } 28 \text { days }\end{array}$ & $\begin{array}{l}\text { No toxic effect in tissues } \\
\text { occurred; no damaging } \\
\text { effect on intestinal } \\
\text { morphology }\end{array}$ & $\begin{array}{l}\text { Dietary SeNP inclusion showed } \\
\text { comparable results with organic } \\
\text { Se at the best dose of } 0.9 \mathrm{mg} / \mathrm{kg} \\
\text { (improved absorption in the } \\
\text { duodenum) }\end{array}$ & [48] \\
\hline $\begin{array}{l}\text { male Arbor } \\
\text { Acres broilers }\end{array}$ & SeNPs & $\begin{array}{l}0.0,0.3,0.5,1.0, \text { or } \\
2.0 \mathrm{mg} / \mathrm{kg} \text { of diet }\end{array}$ & No toxic effect occurred & $\begin{array}{l}0.3-0.5 \mathrm{mg} / \mathrm{kg} \text { optimum doses } \\
\text { improved meat quality, immune } \\
\text { function, and antioxidant status. } \\
\text { Liver and muscle Se contents } \\
\text { increased with SeNP } \\
\text { supplementation }\end{array}$ & [146] \\
\hline Broiler chicken & SeNPs & $0.3 \mathrm{mg} / \mathrm{kg}$ of diet & No toxic effect occurred & $\begin{array}{l}\text { Enhanced Se and vitamin E } \\
\text { concentrations in breast muscles, } \\
\text { improvement of antioxidant and } \\
\text { immune properties }\end{array}$ & [147] \\
\hline Broiler chicken & SeNPs & $4.25 \mathrm{mg} / \mathrm{kg} \mathrm{DM}$ & No toxic effect occurred & $\begin{array}{l}\text { Changes in proteome profile } \\
\text { indicated dietary stress from } \\
\text { SeNPs supplementation }\end{array}$ & [125] \\
\hline $\begin{array}{l}\text { Ross } 308 \text { broiler } \\
\text { chicken }\end{array}$ & SeNPs & $\begin{array}{l}0.1,0.2,0.3,0.4, \text { or } \\
0.5 \mathrm{mg} / \mathrm{kg} \text { of diet }\end{array}$ & No toxic effect occurred & $\begin{array}{l}\text { Dietary SeNPs improved weight } \\
\text { gain, feed conversion ratio, and } \\
\text { growth performance }\end{array}$ & [148] \\
\hline $\begin{array}{l}\text { Ross } 308 \text { broiler } \\
\text { male chicken }\end{array}$ & SeNPs & 0.1 or $0.4 \mathrm{mg} / \mathrm{kg}$ of diet & No toxic effect occurred & $\begin{array}{l}\text { Improved antioxidant status, } \\
\text { better production performance, } \\
\text { and immune system response }\end{array}$ & [149] \\
\hline $\begin{array}{l}\text { Ross broiler } \\
\text { chicken }\end{array}$ & SeNPs & $\begin{array}{c}0.3,0.45 \text {, or } 0.6 \mathrm{mg} / \mathrm{kg} \\
\text { of diet }\end{array}$ & No toxic effect occurred & $\begin{array}{l}\text { Increased body weight gain, } \\
\text { improved feed conversion ratio, } \\
\text { and meat quality }\end{array}$ & [150] \\
\hline Broiler chicken & SeNPs & $\begin{array}{c}0.5,0.8, \text { or } 1.2 \mathrm{mg} / \mathrm{kg} \\
\text { of diet }\end{array}$ & No toxic effect occurred & $\begin{array}{l}\text { SeNPs dietary inclusion improved } \\
\text { performance and immune system } \\
\text { better than diets included SeMet } \\
\text { and vitamin E }\end{array}$ & [151] \\
\hline Broiler chicken & $\begin{array}{l}\text { Biogenic SeNPs } \\
\text { produced using } \\
\text { the bacteria } \\
\text { Pantoea } \\
\text { agglomerans }\end{array}$ & - & No toxic effect occurred & $\begin{array}{l}\text { Protective effect against oxidative } \\
\text { and immune stress }\end{array}$ & [152] \\
\hline
\end{tabular}


Compared to selenite and selenate, SeNPs are more biocompatible and less toxic to animal organisms [14]. Nevertheless, high doses or long-term supplementation of SeNPs may lead to adverse effects in animal organisms and can be toxic. Several in vivo studies were conducted to measure NPs toxicity. Urbankova et al. reported that SeNPs supplementation had fewer negative effects in rats compared to the standard form. In contrast, supranutritional doses of SeNP administration $(0.2,0.4$, and $0.8 \mathrm{mg} / \mathrm{kg}$ of body weight) showed a positive effect on reproductive functions and immune and antioxidant capacity. Other experiments on mice and rats supplemented with SeNPs demonstrated the hepatotoxic effect of SeNPs, which were also confirmed by further histological examination $[47,62,137,138,142]$. Damage to the liver parenchyma and intestinal epithelium in rats was reported after $0.5,1.5,3$, and $5 \mathrm{mg} / \mathrm{kg}$ DM of SeNP supplementation [136]. The authors suggest that short-term SeNP supplementation can be safer and more beneficial in specific treatments. This unfavorable effect could be related to the tested animals' metabolisms, biological characteristics, and the correlation between animal weight and the dosage of NPs administrated. The toxicity of NPs can largely vary among different species [153]. SeNP hyperaccumulation in Pangasius hypophthalmus liver, brain, and muscles was observed after SeNP supplementation (2.5-4 mg/L), which caused oxidative stress and toxicity in fish [154]. In another study, SeNP $(100 \mu \mathrm{g} \mathrm{Se} / \mathrm{L})$ supplementation in Oryzias latipes enhanced oxidative stress caused by the hyperaccumulation of Se in the liver [155].

Based on the studies mentioned above, SeNP supplementation can have many health benefits (e.g., improved production performance, growth, feed efficiency, antioxidant status, and immune status) when present in animal diets compared to inorganic Se sources. Nevertheless, high doses of SeNPs can cause the hyperaccumulation of Se in tissues and oxidative stress or toxicity. Therefore, SeNPs should be included in animal diets in optimum doses to formulate nutritionally balanced feeds. The mechanism of nano-sized Se conversion remains unclear, and the gut microbiota is thought to play a key role in this process. The application of SeNPs showed promising results in improving the oxidative status of the cell induced by a reduction in glutathione (GSH), superoxide dismutase (SOD) levels [156], and GPx activities [157]. Whereas the great advantage of SeNP application compared to sodium selenite can be increased availability of the element [135], on the other hand, this advantage could be turned into a disadvantage through uncontrolled SeNP penetration across cellular membranes, which might be harmful to animal health. According to Surai et al. [35], the metabolism and assimilation of nano-sized Se could be disadvantageous in the animal diet when Se's main mechanism of biological activity is mediated via selenoprotein synthesis. Moreover, the effect of dietary SeNPs on gut health and the formation of the accumulated nano-sized Se in animal tissues after supplementation is still unknown and needs further investigation. Furthermore, the topic of whether SeNPs supplementation may increase Se stores in the body remains unanswered.

\subsection{Green Synthesis of SeNPs}

Over the past decade, the biological method of producing NPs has become an emerging trend in nanotechnology and was developed as a sustainable way to overcome the disadvantages of chemical-based NP synthesis (e.g., high cost and toxic chemicals usage) [104]. Green synthesis provides a new possibility to synthesize NPs via an eco-friendly approach using simple unicellular or multicellular biological entities (e.g., bacteria, fungi, yeast, algae, and plant tissues) as natural reducing and stabilizing agents. The biologically synthesized nanostructures offer substantially different properties such as good adhesion, tribologically good properties, optical and electrical properties, and many promising applications. In NP synthesis, reducing and capping agents play an important role in impacting useful NP properties such as size, morphology, stabilizing, and protecting the NPs' surface, preventing aggregation and uncontrolled growth [158]. Chemical components (i.e., polyethylene glycol, formaldehyde, polyethyleneimine, and polyacrylic acid) used as capping, reducing, stabilizing agents, or solvents in the procedures of chemical NP synthesis are hazardous and extremely toxic $[159,160]$. To be easily utilized in the living 
systems and not cause cellular toxicity, capping agents should be nontoxic, biodegradable, biocompatible, biosoluble, and well dispersed [161]. Green capping agents (e.g., amino acids and polysaccharides) are environmentally friendly. They may lead to designing NPs with unique morphologies and sizes, which can improve, for example, drug delivery via NPs, thereby enhancing NPs' antifungal, antiviral, and antibacterial activity. Nutrients in the form of nanoparticles can be encapsulated in nanocapsules and carried via GIT into the bloodstream and then into body organs, where they enhance the bioavailability of delivered nutrients [162]. Biological synthesis was successfully used to produce different metal NPs, such as AuNPs, FeNPs, and AgNPs [160,163-166]. Green synthesis was also employed to produce SeNPs [167-170], and their antimicrobial, antifungal properties, and cytotoxicity were tested in various in vitro studies.

\subsection{Antimicrobial Potential of SeNp Produced via Green Synthesis}

Antimicrobial resistance (AMR) represents a major global problem, which significantly affects human and animal health. The wide use of antibiotics as growth promoters in animal farming has caused the development of increased antibiotic resistance in numerous bacterial strains. As a consequence, in 2003, the use of antibiotics in livestock diets was banned in the EU [171]. AMR adversely affects animal health, leading to the poor quality of products of animal origin and economic losses. Therefore, finding a new solution to overcome antibiotic usage is strongly needed. In recent years, nanotechnology enabled the manufacture of effective antimicrobial agents from nano-scaled materials, particularly metals. Many studies confirmed the antioxidant, antibacterial, anticancer, and antifungal activities of metallic NPs [86,172-174]. Whereas selenium nanoparticles have attracted scientific interest primarily as a result of research into their anticancer properties; this nanomaterial's antibacterial potential has recently been identified. NPs have a large surface area, which increases the area of interaction with pathogenic microorganisms. Furthermore, due to the nano size, they are more likely to enter bacterial surfaces.

Although most of the studies on the antimicrobial potential of biogenic SeNPs were conducted in vitro (Table 4), the results of these studies showed noticeable antibacterial, antifungal, and anticancer SeNPs activities against many important humans and animal pathogens and their potential for future applications in nanomedicine and veterinary. Furthermore, SeNPs produced through the green way show lower cytotoxicity, greater bioavailability, and reactivity than inorganic and organic Se, which makes them an attractive candidate for future therapeutic applications. The therapeutic effect of biogenic SeNPs $(2.5,5.0$, and $10.0 \mathrm{mg})$ was also confirmed in an in vitro experiment in a mouse model infected with Toxoplasma gondii with no cytotoxicity observed [107]. Based on in vitro studies (Table 4), SeNPs represent a viable approach to inhibit bacterial growth without using antibiotics and to overcome the drawbacks of synthetic methods that employ toxic chemicals. Interesting results were obtained by Cremonini et al. [175] who demonstrated the significantly better antibacterial activity of biogenic SeNPs in comparison with chemically produced NPs.

Table 4. Effects of biogenic SeNPs tested in vitro with potential use in nutrition.

\begin{tabular}{|c|c|c|c|c|c|}
\hline $\begin{array}{l}\text { Biological Organism } \\
\text { Used for NPs } \\
\text { Synthesis }\end{array}$ & $\begin{array}{l}\text { NPs Characterization } \\
\text { (Size, Shape) }\end{array}$ & Applied Dose & Pathogens/Cells & Effect & Reference \\
\hline $\begin{array}{l}\text { Cyanobacteria } \\
\text { Anabaena sp. }\end{array}$ & Spherical NPs 5-50 nm & $50 \mu \mathrm{g} / \mathrm{mL}$ & $\begin{array}{l}\text { Gram-positive and } \\
\text { Gram-negative } \\
\text { strains of } \\
\text { Staphylococcus aureus } \\
\text { and Escherichia coli }\end{array}$ & $\begin{array}{ll}\text { - } & \text { Antibiofilm and } \\
\text { antimicrobial activity } \\
\text { - } \quad \text { Cytotoxicity (apoptosis) } \\
\text { in HeLa cells }\end{array}$ & [176] \\
\hline $\begin{array}{l}\text { Lactobacillus casei } \\
\quad \text { ATCC } 393\end{array}$ & $50-80 \mathrm{~nm}$ & $8 \mu \mathrm{g} \mathrm{Se} / \mathrm{mL}$ & $\begin{array}{l}\text { The porcine jejunal } \\
\text { epithelial cell line } \\
\text { (IPEC-J2) }\end{array}$ & 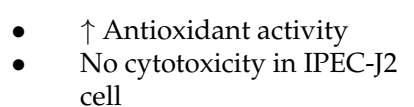 & [177] \\
\hline
\end{tabular}


Table 4. Cont

\begin{tabular}{|c|c|c|c|c|c|}
\hline $\begin{array}{l}\text { Biological Organism } \\
\text { Used for NPs } \\
\text { Synthesis }\end{array}$ & $\begin{array}{c}\text { NPs } \\
\text { Characterization } \\
\text { (Size, Shape) }\end{array}$ & Applied Dose & Pathogens/Cells & Effect & Reference \\
\hline $\begin{array}{l}\text { Citrus fruit (Citrus } \\
\text { limon, Citrus paradise) } \\
\text { extracts }\end{array}$ & $100-800 \mathrm{~nm}$ & 10 and $12 \mathrm{mM}$ & $\begin{array}{l}\text { E. coli, Micrococcus } \\
\text { luteus, Bacillus subtilis, } \\
\text { and Klebsiella } \\
\text { pneumoniae }\end{array}$ & - $\quad \uparrow$ Antimicrobial effect & [178] \\
\hline Mushroom extract & $8 \mathrm{~nm}$ & $0.5-1.5 \mu \mathrm{M}$ & Gram-negative E.coli & $\begin{array}{ll}\text { - } & \uparrow \text { Antimicrobial activity } \\
\text { - } & \text { No cytotoxicity in } \\
\text { - } & \text { prostate cancer cell lines } \\
& \text { Antioxidant activity }\end{array}$ & [179] \\
\hline $\begin{array}{c}\text { Brown alga } \\
\text { Sargassum swartzii }\end{array}$ & $21 \mathrm{~nm}$ & $10 \mathrm{mg} / \mathrm{mL}$ & V. parahaemolyticus & - $\quad \uparrow$ Bacterial inhibition & [180] \\
\hline Bacillus licheniformis & $110 \mathrm{~nm}$ & $2 \mathrm{mg} / \mathrm{mL}$ & Cancer cells & $\begin{array}{l}\text { - } \quad \uparrow \text { TNF; induced cell death; } \\
\text { - } \quad \uparrow \operatorname{ROS}\end{array}$ & [181] \\
\hline $\begin{array}{l}\text { Yeast Magnusiomyces } \\
\quad \text { ingens LH-F1 }\end{array}$ & $\begin{array}{l}\text { Spherical; average } \\
\text { size } 87.82 \mathrm{~nm}\end{array}$ & No information & $\begin{array}{c}\text { Gram-positive } \\
\text { Arthrobacter sp. W1 } \\
\text { Gram-negative E. coli } \\
\text { BL21 }\end{array}$ & $\begin{array}{l}\text { Inhibition against } \\
\text { Arthrobacter but not } \\
\text { against E. coli }\end{array}$ & [182] \\
\hline $\begin{array}{c}\text { Trichoderma } \\
\text { harzianum JF309 }\end{array}$ & - & $400 \mu \mathrm{g} / \mathrm{mL}$ & $\begin{array}{l}\text { Alternaria toxins, } \\
\text { Fusarium verticillioide, } \\
\text { and F. graminearum }\end{array}$ & $\begin{array}{l}\text { Antifungal effects against } \\
\text { Alternaria toxins; } \\
\text { fumonisin B1; } \\
\text { deoxynivalenol } \\
\text { - No cytotoxicity in } \\
\text { human cells }\end{array}$ & [183] \\
\hline Zingiber officinale & $100-150 \mathrm{~nm}$ & $250 \mu \mathrm{g} / \mathrm{mL}$ & $\begin{array}{l}\text { E. coli, Klebsiella sp., } \\
\text { Pseudomonas sp., } \\
\text { Staphylococcus aureus, } \\
\text { and Proteus sp. }\end{array}$ & $\begin{array}{l}-\quad \uparrow \text { Antimicrobial activity } \\
-\quad \uparrow \mathrm{DPPH}\end{array}$ & [184] \\
\hline $\begin{array}{l}\text { Ceropegia bulbosa } \\
\text { tuber's aqueous } \\
\text { extracts extract }\end{array}$ & $277.5 \mathrm{~nm}$ & $\begin{array}{l}25,50,75, \text { and } \\
100 \mu \mathrm{L} / \mathrm{mL}\end{array}$ & E. coli and B. subtilis & $\begin{array}{ll}- & \uparrow \text { Antimicrobial activity } \\
- & \uparrow \text { Antilarval activity } \\
- & \uparrow \text { Cytotoxicity in the } \\
& \text { human breast cancer cells } \\
& \text { at dose } 34 \mu \mathrm{g} / \mathrm{mL} ; \\
& \text { anticancer efficacy } \\
\text { - No cytotoxicity in } \\
\text { human cells }\end{array}$ & [185] \\
\hline $\begin{array}{l}\text { SeNPs synthesized } \\
\text { by the green method } \\
\text { (no information } \\
\text { about organism used } \\
\text { for preparation) }\end{array}$ & $60 \mathrm{~nm}$ & $\begin{array}{l}0.3,0.4, \text { and } \\
0.5 \mathrm{mg} / \mathrm{mL}\end{array}$ & $\begin{array}{l}\text { E. coli and Candida } \\
\text { albicans }\end{array}$ & $\begin{array}{l}\text { - } \quad \uparrow \text { Antimicrobial activity at } \\
\text { all SeNPs concentrations }\end{array}$ & \\
\hline $\begin{array}{l}\text { The aqueous filtrate } \\
\text { of Spirulina platensis }\end{array}$ & $\begin{array}{l}\text { Average size } 79.40 \\
\mathrm{~nm} \text {, spherical shape }\end{array}$ & 5 and $10 \mathrm{mM}$ & $\begin{array}{l}\text { C. albicans, Klebsiella } \\
\text { pneumoniae, and } \\
\text { Salmonella abony }\end{array}$ & $\begin{array}{ll}\text { - } & \text { No cytotoxicity in liver } \\
\text { and kidney cells } \\
\text { - } & \uparrow \text { Antimicrobial activity }\end{array}$ & [186] \\
\hline $\begin{array}{l}\text { Escherichia coli, } \\
\text { Pseudomonas } \\
\text { aeruginosa, } \\
\text { Methicillin-resistant } \\
\text { Staphylococcus aureus, } \\
\text { and S. aureus }\end{array}$ & $90-150 \mathrm{~nm}$ & $25-250 \mu \mathrm{g} / \mathrm{mL}$ & E. coli and S. aureus & $\begin{array}{l}\text { - } \quad \begin{array}{l}\text { Antimicrobial activity } \\
\text { - }\end{array} \\
\text { human cytotoxicity in } \\
\text { human cells }\end{array}$ & [187] \\
\hline $\begin{array}{l}\text { Gram-negative } \\
\text { Stenotrophomonas } \\
\text { maltophilia and } \\
\text { Gram-positive } \\
\text { Bacillus mycoides }\end{array}$ & $\begin{array}{l}160.6 \mathrm{~nm} \text { for } \mathrm{G}+ \\
170.6 \mathrm{~nm} \text { for } \mathrm{G}-\end{array}$ & $\begin{array}{l}50,100, \text { and } \\
250 \mu \mathrm{g} / \mathrm{mL}\end{array}$ & $\begin{array}{l}\text { C. albicans, C. } \\
\text { parapsilosis, and } \\
\text { Pseudomonas } \\
\text { aeruginosa }\end{array}$ & $\begin{array}{ll}\text { - } & \uparrow \text { Antimicrobial activity } \\
\text { - } & \quad \downarrow \text { Anainst P. aeruginosa } \\
& \text { against Candida sp. } \\
\text { - } \quad \text { No cytotoxicity }\end{array}$ & [175] \\
\hline
\end{tabular}


Table 4. Cont.

\begin{tabular}{|c|c|c|c|c|c|}
\hline $\begin{array}{l}\text { Biological Organism } \\
\text { Used for NPs } \\
\text { Synthesis }\end{array}$ & $\begin{array}{l}\text { NPs Characterization } \\
\text { (Size, Shape) }\end{array}$ & Applied Dose & Pathogens/Cells & Effect & Reference \\
\hline 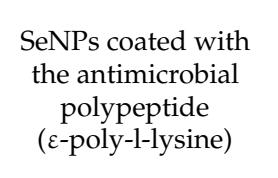 & $80 \mathrm{~nm}$ & $\begin{array}{l}5,10,25, \text { and } \\
50 \mu \mathrm{g} / \mathrm{mL}\end{array}$ & $\begin{array}{l}\text { Enterococcus faecalis, } \\
\text { E. coli, P. aeruginosa, S. } \\
\text { aureus, K. pneumoniae, } \\
\text { and K. }\end{array}$ & 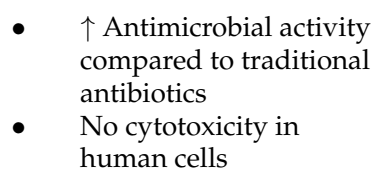 & [188] \\
\hline
\end{tabular}

$\uparrow$ higher level; $\downarrow$ lower level; G+ gram-positive bacteria; G- gram-negative bacteria.

The strengths, weaknesses, opportunities, and threats (SWOT) analysis for a brief overview of advances and weaknesses of SeNP application in animal nutrition is proposed in Figure 1.

\section{Biogenic SeNPs}
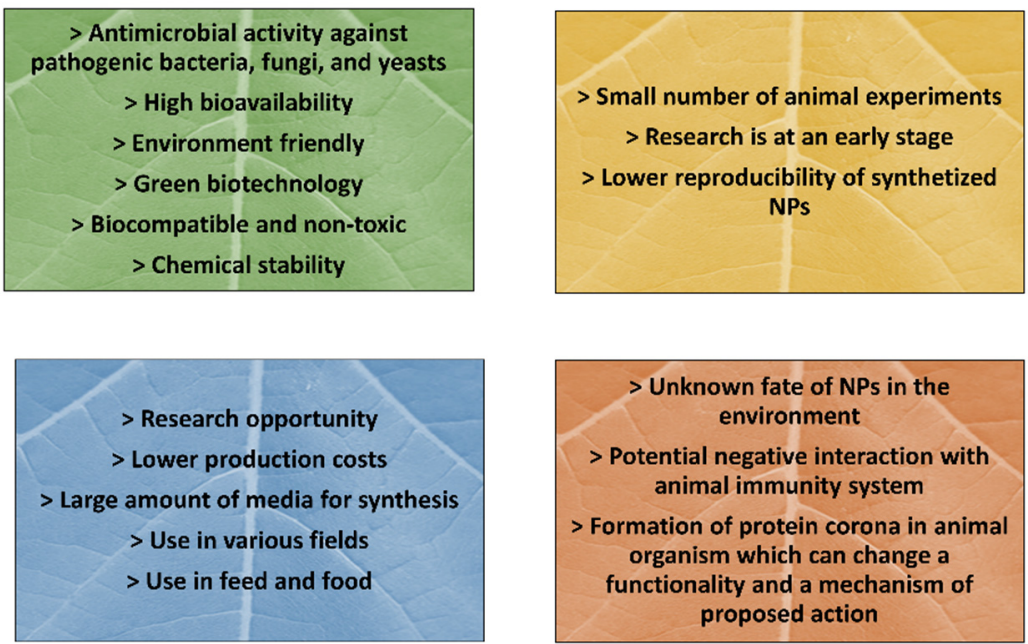

Figure 1. The strengths, weaknesses, opportunities, and threats (SWOT) analysis of SeNP application in animal nutrition.

\subsection{Synthesis by Plants and Microorganisms}

Live plants; plant tissues; and extracts from the plant leaf, latex, root, seed, and stem, or the whole plant have also been used to synthesize NPs, as they act as stabilizing or reducing agents $[189,190]$. Due to their genetic variability, plants possess many interesting metabolites, such as phenolic compounds, alkaloids, and sterols, that can serve as excellent biocapping and/or reducing agents. In NPs biosynthesis, plant polyphenols, which possess hydroxyl reducing groups, are usually used as stabilizing and reducing agents. Hydroxyl groups of biologically active plant compounds can also act as a capping agent by depositing on the NPs' surfaces. Polyphenols and proteins may play a key role in reducing selenium ions to their element and stabilizing the SeNPs' form [191]. Polysaccharides may effectively improve the NPs' stability and morphology [192]. The different preparation methods of the plant extract from the same plant tissue may also significantly affect the shape, size, and distribution of NPs [193].

Singh et al. [193] used different Zingiber officinale rhizome extract preparation methods and obtained NPs with different properties. The significant advantage of plant-mediated NP synthesis is the inexpensiveness of culture compared to synthesis using microorganisms. In addition, it reduces the cost of microorganism isolation and further NP purification [194]. Moreover, plant-mediated NPs are stable, reproducible, environmentally friendly, and less time-consuming to produce [195]. Anu et al. [167] used Allium sativum 
extract to produce SeNPs and synthesized NPs 40-100 nm in size, showing decreased cytotoxicity compared to chemically produced SeNPs. SeNPs mediated from various plant extracts (e.g., Diospyros Montana, Murraya koenigii, Ephedra aphylla, and Thymus vulgaris) were reported to have antifungal, anticancer, and antimicrobial activity $[108,168,196,197]$. Green synthesis of SeNPs is commonly achieved by reducing selenate/selenite in the presence of bacterial proteins and plant extracts containing various metabolites such as phenols, flavonoids, alcohols, and proteins. Many microorganisms (e.g., Herbaspirillum sp., Bacillus arseniciselenatis, B. selenitireducens, and Comamonas testosteroni) have been observed to reduce toxic selenate and selenite into the nontoxic element selenium through aerobic or anaerobic conditions $[189,198,199]$. Microbes can produce NPs either intra- or extracellularly via different bioreduction processes using various microbial enzymes [190]. Microbial NP synthesis includes two reduction processes (reduction from selenate to selenium trioxide and then to elemental selenium), catalyzed by selenite and selenate reductases [200].

The study conducted by El-Saadony et al. [201] showed that SeNPs synthesized using Lactobacillus paracasei had an antagonistic effect against pathogenic fungi and significantly inhibited the growth of Candida and Fusarium species, which are the most known animal pathogenic species. Moreover, the diameter of obtained SeNPs ranges from 30 to $50 \mathrm{~nm}$. In comparison, a previous study by Sasidharan and Balakrishnaraja [202] synthesized SeNPs by bacteria species (Lactobacillus casei; Streptococcus thermophilus; Bifidobacterium; Lactobacillus acidophilus; Lactobacillus helveticus; Klebsiella pneumoniae), but the disadvantage was the size of the produced NPs ranged from 50 to $550 \mathrm{~nm}$. SeNPs synthesized using various cyanobacteria extracts (e.g., Nostoc sphericum, N. punctiforne, Spirulina pratensis, and Athrospira indica) showed good antioxidant activities and are recommended for future use as food supplements [203].

SeNPs can play an important role in eliminating microbial infections and, thus, improving animals' growth and performance. SeNPs can inhibit both Gram-negative and Gram-positive bacteria by interrupting microbial biofilm [204] and possess significant antifungal activity by inhibiting spore germination [153]. The antifungal activity of SeNPs was tested mostly by in vitro experiments, and more extensive research in this field is needed. Shakibaie et al. [106] demonstrated a good potential of using bacteria Bacillus sp. for SeNPs synthesis. SeNPs prepared using these bacteria were orally administered to male mice, and biogenic SeNPs showed significantly less toxicity than synthetic SeNPs and $\mathrm{SeO}_{2}$.

Nevertheless, the reason for such a difference is not clear. Some in vivo experiments with biogenic SeNP dietary inclusion showed an improved oxidative status in tested animals without toxic effects $[125,153,154]$. Shirsat et al. [205] demonstrated a protective effect against the oxidative and immune stress of biogenic SeNPs synthesized using the bacteria Pantoea agglomerans in broilers' diets. Song et al. obtained promising results, which used yeast Kluyveromyces lactis GG799 for SeNPs production. SeNPs demonstrated no toxicity in mice. Moreover, dietary supplementation with $0.6 \mathrm{mg} / \mathrm{kg}$ Se effectively attenuated oxidative stress, intestinal inflammation, and intestinal barrier dysfunction. However, these experiments are only a few, and further investigation of the impact of biogenic NPs on animals' performance and production is required.

\subsection{Synthesis of SeNPs by Marine Algae and Microalgae}

Marine algae generally contain a wide spectrum of biologically active compounds such as polysaccharides, proteins, PUFA, various pigments, and antioxidants. Considering this spectrum, it predestines them to diverse commercial applications [206]. Marine algae may represent a novel nanotechnological solution that could facilitate the application of new alga-mediated NPs in medicine and animal nutrition. Some algae (e.g., Chlorella vulgaris, Sargassum wightii, Spirogyra insignis, Chondrus crispus, and Tetraselmis kochinensis) were used for the synthesis of metallic NPs such as Ag and Au NPs [207-210]. SeNPs synthesized via Spirulina pratensis showed antibacterial activity against foodborne microorganisms 
(Staphylococcus aureus and Salmonella typhimurium), but antibacterial activity increased with NP size reduction [211]. Aqueous extract of algae Sargassum angustifolium was used for biosynthesis of SeNPs, which were finally examined on antibacterial activity. Algae-coated SeNPs showed better antibacterial activity against Vibrio harveyi compared to uncoated SeNPs [212]. Algal cell walls are mainly composed of polysaccharides, natural polymers containing monosaccharides linked with glycosidic bonds. In recent years, the application of diverse algal polysaccharides (e.g., alginate and laminarin) has been reported [213]. Developing drug delivery systems using seaweed polysaccharides has received special attention in the scientific community due to the important field of biomedical research. Algal polysaccharides were successfully used for coating NPs as a stabilizing agent. The hydrophilic surface of functional groups on polysaccharides (e.g., hydroxyl, sulfate, and carboxyl groups) allows them to easily interact with biological tissues. Therefore, algal polysaccharides can serve as an excellent template for NP synthesis in modern nanotechnology.

Colloidal stability is frequently an issue that requires significant consideration since high agglomeration levels have been recorded in some situations [214]. The use of algae in NP production is also limited due to the lack of understanding of the synthesis mechanism. Studies regarding the employment of marine algae for SeNP production are still ongoing. It is believed to have a wide potential in the synthesis of biogenic NPs with interesting new properties.

\section{Conclusions}

The role of selenium in animals is reviewed and discussed. Selenium deficiency can lead to many diseases in animals, as can selenium overdose. The bioavailability of Se depends on the chemical form of supplementation and animal species exposed to a Seenriched diet and requires further investigation. Nanotechnology offers novel "intelligent" solutions in animal nutrition, health protection, and animal production systems. There are many applications of NPs in animal production, but the results of various studies that have evaluated the effects of dietary SeNP inclusion are ambiguous. The biological synthesis of SeNPs using bacteria, plants, and algae shows a great opportunity for further application in various fields as well in animal nutrition and production. Thus, further detailed studies in this field are required to achieve more optimized green methods of NP synthesis and application in animal diets.

Author Contributions: Conceptualization, S.M. and S.S.; writing-original draft preparation, S.M., P.H., and S.S.; writing—review and editing, P.H., S.S., J.S., P.S. and S.M.; supervision, P.H.; project administration, J.S. and P.H.; funding acquisition, P.H. and S.M. All authors have read and agreed to the published version of the manuscript.

Funding: This research was funded by the Technological Agency of the Czech Republic (TACR) from the project TJ04000198.

Institutional Review Board Statement: Not applicable.

Informed Consent Statement: Not applicable.

Data Availability Statement: The data presented in this study are available upon request from the corresponding author.

Acknowledgments: The review article was supported by funding from the Technological Agency of the Czech Republic (TACR) from the project TJ04000198. The authors would also like thank the editor for their useful comments and suggestions, as well as two reviewers.

Conflicts of Interest: The authors declare no conflict of interest regarding of publication of this article. 


\section{References}

1. Kurokawa, S.; Berry, M.J. Selenium. Role of the essential metalloid in health. In Interrelations between Essential Metal Ions and Human Diseases; Springer: Cham, Switzerland, 2013; pp. 499-534.

2. Moxon, A.L. Alkali Disease or Selenium Poisoning. Bulletins 1937, 311. [CrossRef]

3. White, P.J. Selenium accumulation by plants. Ann. Bot. 2015, 117, 217-235. [CrossRef]

4. Doj, R.; Khanal, D.; Knight, A. Selenium: Its Role in Livestock Health and Productivity. J. Agric. Environ. 2010, 11, 101-106. [CrossRef]

5. Garousi, F. The essentiality of selenium for humans, animals, and plants, and the role of selenium in plant metabolism and physiology. Acta Univ. Sapientiae Aliment 2017, 10, 75-90. [CrossRef]

6. James, L.F.; Shupe, J.L. Selenium poisoning in livestock. Rangelands 1984, 6, 64-67.

7. Pilon-Smits, E.A.H. On the Ecology of Selenium Accumulation in Plants. Plants 2019, 8, 197. [CrossRef]

8. Carlson, B.A.; Yoo, M.H.; Shrimali, R.K.; Irons, R.; Gladyshev, V.N.; Hatfield, D.L.; Park, J.M. Role of selenium-containing proteins in T-cell and macrophage function. Proc. Nutr. Soc. 2010, 69, 300-310. [CrossRef]

9. Antonyak, H.; Iskra, R.; Panas, N.; Lysiuk, R. Selenium. In Trace Elements and Minerals in Health and Longevity. Healthy Ageing and Longevity; Malavolta, M., Mocchegiani, E., Eds.; Springer: Cham, Switzerland, 2018; Volume 8.

10. Labunskyy, V.M.; Hatfield, D.L.; Gladyshev, V.N. Selenoproteins: Molecular pathways and physiological roles. Physiol. Rev. 2014, 94, 739-777. [CrossRef]

11. Horký, P.; Skladanka, J.; Nevrkla, P.; Slama, P. 16. Effect of Diet Supplemented with Antioxidants (Selenium, Copper, Vitamins E and C) on Antioxidant Status and Ejaculate Quality of reeding Boars. Ann. Anim. Sci. 2016, 16, 521-532. [CrossRef]

12. Tóth, R.J.; Csapó, J. The role of selenium in nutrition-A review. Acta Univ. Sapientiae Aliment 2018, 11, 128-144. [CrossRef]

13. Wachowicz, B.; Zbikowska, H.; Nowak, P. Selenium compounds in the environment; Their effect on human health. Cell. Mol. Biol. Lett. 2001, 6, 375-381.

14. Skalickova, S.; Milosavljevic, V.; Cihalova, K.; Horky, P.; Richtera, L.; Adam, V. Selenium nanoparticles as a nutritional supplement. Nutrition 2017, 33, 83-90. [CrossRef] [PubMed]

15. Sharadamma, K.C.; Purushotham, B.; Radhakrishna, P.M.; Abhilekha, P.M.; Vagdevi, H.M. Role of Selenium in Pets Health and Nutrition: A Review. Asian J. Anim. Sci. 2011, 5, 64-70. [CrossRef]

16. Edens, F.W.; Sefton, A.E. Organic selenium in animal nutrition-Utilisation, metabolism, storage and comparison with other selenium sources. J. Appl. Anim. Nutr. 2016, 4, e9. [CrossRef]

17. Shini, S.; Sultan, A.; Bryden, W.L. Selenium Biochemistry and Bioavailability: Implications for Animal Agriculture. Agriculture 2015, 5, 1277-1288. [CrossRef]

18. Saha, U.K.; Fayiga, A.O.; Hancock, D.W.; Sonon, L.S. Selenium in Animal Nutrition: Deficiencies in Soils and Forages, Requirements, Supplementation and Toxicity. Int. J. Appl. Agric. Sci. 2016, 2, 112. [CrossRef]

19. Mehdi, Y.; Dufrasne, I. Selenium in Cattle: A Review. Molecules 2016, 21, 545. [CrossRef]

20. Sobiech, P.; Żarczyńska, K. The influence of selenium deficiency on chosen biochemical parameters and histopathological changes in muscles of goat kids. Pol. J. Vet. Sci. 2020, 23, 267-279. [CrossRef]

21. Rodriguez, A.M.; Schild, C.O.; Cantón, G.J.; Riet-Correa, F.; Armendano, J.I.; Caffarena, R.D.; Brambilla, E.C.; García, J.A.; Morrell, E.L.; Poppenga, R.; et al. White muscle disease in three selenium deficient beef and dairy calves in Argentina and Uruguay. Ciência Rural 2018, 48. [CrossRef]

22. Hosnedlova, B.; Kepinska, M.; Skalickova, S.; Fernandez, C.; Ruttkay-Nedecky, B.; Malevu, T.D.; Sochor, J.; Baron, M.; Melcova, M.; Zidkova, J.; et al. A Summary of New Findings on the Biological Effects of Selenium in Selected Animal Species-A Critical Review. Int. J. Mol. Sci. 2017, 18, 2209. [CrossRef]

23. Zhang, Y.; Yu, D.; Zhang, J.; Bao, J.; Tang, C.; Zhang, Z. The role of necroptosis and apoptosis through the oxidative stress pathway in the liver of selenium-deficient swine. Metallomics 2020, 12, 607-616. [CrossRef]

24. Xiao, J.; Khan, M.Z.; Ma, Y.; Alugongo, G.M.; Ma, J.; Chen, T.; Khan, A.; Cao, Z. The Antioxidant Properties of Selenium and Vitamin E.; Their Role in Periparturient Dairy Cattle Health Regulation. Antioxidants 2021, 10, 1555. [CrossRef]

25. Zhang, Y.; Xu, Y.; Chen, B.; Zhao, B.; Gao, X.-J. Selenium Deficiency Promotes Oxidative Stress-Induced Mastitis via Activating the NF-kB and MAPK Pathways in Dairy Cow. Biol. Trace Elem. Res. 2021. [CrossRef]

26. O'Brien, B.; Hennessy, D. Scientific appraisal of the Irish grass-based milk production system as a sustainable source of premium quality milk and dairy products. Irish J. Agric. Food Res. 2017, 56, 120-129. [CrossRef]

27. Zust, J.; Hrovatin, B.; Simundić, B. Assessment of selenium and vitamin E deficiencies in dairy herds and clinical disease in calves. Vet. Rec. 1996, 139, 391-394. [CrossRef]

28. Ademi, A.; Bernhoft, A.; Govasmark, E.; Bytyqi, H.; Sivertsen, T.; Singh, B.R. Selenium and other mineral concentrations in feed and sheep's blood in Kosovo. Transl. Anim. Sci. 2017, 1, 97-107. [CrossRef] [PubMed]

29. Hall, J.A.; Bobe, G.; Vorachek, W.R.; Hugejiletu; Gorman, M.E.; Mosher, W.D.; Pirelli, G.J. Effects of feeding selenium-enriched alfalfa hay on immunity and health of weaned beef calves. Biol. Trace Elem. Res. 2013, 156, 96-110. [CrossRef]

30. Tolu, J.; Thiry, Y.; Bueno, M.; Jolivet, C.; Potin-Gautier, M.; Le Hécho, I. Distribution and speciation of ambient selenium in contrasted soils, from mineral to organic rich. Sci. Total Environ. 2014, 479-480, 93-101. [CrossRef] [PubMed]

31. Galgan, V.; Frank, A. Survey of bioavailable selenium in Sweden with the moose (Alces alces L.) as monitoring animal. Sci. Total Environ. 1995, 172, 37-45. [CrossRef] 
32. Alfthan, G.; Eurola, M.; Ekholm, P.; Venäläinen, E.R.; Root, T.; Korkalainen, K.; Hartikainen, H.; Salminen, P.; Hietaniemi, V.; Aspila, P.; et al. Effects of nationwide addition of selenium to fertilizers on foods, and animal and human health in Finland: From deficiency to optimal selenium status of the population. J. Trace Elem. Med. Biol. 2015, 31, 142-147. [CrossRef]

33. Lemly, D. Aquatic selenium pollution is a global environmental safety issue. Ecotoxicol. Environ. Saf. 2004, 59, 44-56. [CrossRef]

34. National Academies of Sciences, Engineering, and Medicine. Nutrient Requirements of Beef Cattle; The National Research Council: Washington, DC, USA, 2016.

35. Surai, P.F.; Kochish, I.I. Food for thought: Nano-selenium in poultry nutrition and health. Anim. Health Res. Rev. 2020, 21, 103-107. [CrossRef] [PubMed]

36. Mavromichalis, I. Formulating Pig Diets: Selenium Toxicity, Deficiency. Available online: https://www.wattagnet.com/articles/ 19843-formulating-pig-diets-selenium-toxicity-deficiency (accessed on 3 November 2021).

37. National Research Council. Nutrient Requirements of Swine; National Academies Press: Washington, DC, USA, 2012.

38. Olson, O.E. Selenium Toxicity in Animals with Emphasis on Man. J. Am. Coll. Toxicol. 1986, 5, 45-70. [CrossRef]

39. Hall, J.O. Acute Selenium Toxicosis. In Merck Veterinary Manual; Utah State University: Logan, UT, USA, 2014.

40. National Research Council. Nutrient Requirements of Small Ruminants: Sheep, Goats, Cervids, and New World Camelids; The National Academies Press: Washington, DC, USA, 2007; p. 384.

41. Van Saun, R.J. Selenium nutrition and therapy in small ruminants. In Proceedings of the American Association of Bovine Practitioners Proceedings of the Annual Conference, Montreal, QC, Canada, 20-22 September 2012; pp. 148-154.

42. Council, N.R. Nutrient Requirements of Horses: Sixth Revised Edition; The National Academies Press: Washington, DC, USA, 2007; p. 360 .

43. Arshad, M.A.; Ebeid, H.M.; Hassan, F.-U. Revisiting the Effects of Different Dietary Sources of Selenium on the Health and Performance of Dairy Animals: A Review. Biol. Trace Elem. Res. 2021, 199, 3319-3337. [CrossRef]

44. McDowell. Minerals in Animal and Human Nutrition; Elsevier: Amsterdam, The Netherlands, 2003.

45. Sun, P.; Wang, J.; Liu, W.; Bu, D.P.; Liu, S.J.; Zhang, K.Z. Hydroxy-selenomethionine: A novel organic selenium source that improves antioxidant status and selenium concentrations in milk and plasma of mid-lactation dairy cows. J. Dairy Sci. 2017, 100, 9602-9610. [CrossRef]

46. Singh, J.; Dutta, T.; Kim, K.-H.; Rawat, M.; Samddar, P.; Kumar, P. ‘Green' synthesis of metals and their oxide nanoparticles: Applications for environmental remediation. J. Nanobiotechnol. 2018, 16, 84. [CrossRef]

47. Bhattacharjee, A.; Basu, A.; Bhattacharya, S. Selenium nanoparticles are less toxic than inorganic and organic selenium to mice in vivo. Nucleus 2019, 62, 259-268. [CrossRef]

48. Gangadoo, S.; Dinev, I.; Willson, N.L.; Moore, R.J.; Chapman, J.; Stanley, D. Nanoparticles of selenium as high bioavailable and non-toxic supplement alternatives for broiler chickens. Environ. Sci. Pollut. Res. Int. 2020, 27, 16159-16166. [CrossRef]

49. Hosnedlova, B.; Kepinska, M.; Skalickova, S.; Fernandez, C.; Ruttkay-Nedecky, B.; Peng, Q.; Baron, M.; Melcova, M.; Opatrilova, R.; Zidkova, J.; et al. Nano-selenium and its nanomedicine applications: A critical review. Int. J. Nanomed. 2018, 13, 2107-2128. [CrossRef]

50. Schlegel, P.; Durosoy, S.; Jongbloed, A.W. Trace Elements in Animal Production Systems; Wageningen Academic Publishers: Wageningen, The Netherlands, 2008.

51. Mahima; Verma, A.; Kumar, A.; Rahal, A.; Sidhu, V.K.; Roy, D. Inorganic versus organic selenium supplementation: A Review. Pak. J. Biol. Sci. PJBS 2012, 15, 418-425. [CrossRef] [PubMed]

52. Schrauzer, G.N. The nutritional significance, metabolism and toxicology of selenomethionine. Adv. Food Nutr. Res. 2003, 47, 73-112. [CrossRef]

53. Zoidis, E.; Seremelis, I.; Kontopoulos, N.; Danezis, G.P. Selenium-Dependent Antioxidant Enzymes: Actions and Properties of Selenoproteins. Antioxidants 2018, 7, 66. [CrossRef] [PubMed]

54. Ghaderzadeh, S.; Mirzaei Aghjeh-Gheshlagh, F.; Nikbin, S.; Navidshad, B. Review on properties of selenium in animal nutrition. Iran. J. Appl. Anim. Sci. 2016, 6, 753-761.

55. Rehman, A.; John, P.; Bhatti, A. Biogenic Selenium Nanoparticles: Potential Solution to Oxidative Stress Mediated Inflammation in Rheumatoid Arthritis and Associated Complications. Nanomaterials 2021, 11, 2005. [CrossRef] [PubMed]

56. Stefanowicz, F.A.; Talwar, D.; O’Reilly, D.S.; Dickinson, N.; Atkinson, J.; Hursthouse, A.S.; Rankin, J.; Duncan, A. Erythrocyte selenium concentration as a marker of selenium status. Clin. Nutr. 2013, 32, 837-842. [CrossRef]

57. Grossi, S.; Rossi, L.; De Marco, M.; Sgoifo Rossi, C.A. The Effect of Different Sources of Selenium Supplementation on the Meat Quality Traits of Young Charolaise Bulls during the Finishing Phase. Antioxidants 2021, 10, 596. [CrossRef]

58. Mehdi, Y.; Hornick, J.-L.; Istasse, L.; Dufrasne, I. Selenium in the Environment, Metabolism and Involvement in Body Functions. Molecules 2013, 18, 3292-3311. [CrossRef]

59. Surai, P.F.; Kochish, I.I.; Fisinin, V.I.; Velichko, O.A. Selenium in Poultry Nutrition: From Sodium Selenite to Organic Selenium Sources. J. Poult. Sci. 2018, 55, 79-93. [CrossRef]

60. Sunde, R.A. Molecular Biology of Selenoproteins. Annu. Rev. Nutr. 1990, 10, 451-474. [CrossRef]

61. Dalgaard, T.S.; Briens, M.; Engberg, R.M.; Lauridsen, C. The influence of selenium and selenoproteins on immune responses of poultry and pigs. Anim. Feed Sci. Technol. 2018, 238, 73-83. [CrossRef] 
62. Romero-Pérez, A.; García-García, E.; Zavaleta-Mancera, A.; Ramírez-Bribiesca, J.E.; Revilla-Vázquez, A.; Hernández-Calva, L.M.; López-Arellano, R.; Cruz-Monterrosa, R.G. Designing and evaluation of sodium selenite nanoparticles in vitro to improve selenium absorption in ruminants. Vet. Res. Commun. 2010, 34, 71-79. [CrossRef]

63. Whanger, P.D. Selenocompounds in plants and animals and their biological significance. J. Am. Coll. Nutr. 2002, $21,223-232$. [CrossRef] [PubMed]

64. Kieliszek, M.; Błażejak, S.; Gientka, I.; Bzducha-Wróbel, A. Accumulation and metabolism of selenium by yeast cells. Appl. Microbiol. Biotechnol. 2015, 99, 5373-5382. [CrossRef] [PubMed]

65. Vignola, G.; Lambertini, L.; Mazzone, G.; Giammarco, M.; Tassinari, M.; Martelli, G.; Bertin, G. Effects of selenium source and level of supplementation on the performance and meat quality of lambs. Meat Sci. 2009, 81, 678-685. [CrossRef] [PubMed]

66. Paiva, F.A.; Netto, A.S.; Corrêa, L.B.; Silva, T.H.; Guimarães, I.C.S.B.; Claro, G.R.d.; Cunha, J.A.; Zanetti, M.A. Organic selenium supplementation increases muscle selenium content in growing lambs compared to inorganic source. Small Rumin. Res. 2019, 175, 57-64. [CrossRef]

67. Steen, A.; Strøm, T.; Bernhoft, A. Organic selenium supplementation increased selenium concentrations in ewe and newborn lamb blood and in slaughter lamb meat compared to inorganic selenium supplementation. Acta Vet. Scand. 2008, 50, 7. [CrossRef] [PubMed]

68. Silva, J.S.; Rodriguez, F.D.; Trettel, M.; Abal, R.T.; Lima, C.G.; Yoshikawa, C.Y.C.; Zanetti, M.A. Performance, carcass characteristics and meat quality of Nellore cattle supplemented with supranutritional doses of sodium selenite or selenium-enriched yeast. Animal 2020, 14, 215-222. [CrossRef]

69. Hall, J.A.; Van Saun, R.J.; Bobe, G.; Stewart, W.C.; Vorachek, W.R.; Mosher, W.D.; Nichols, T.; Forsberg, N.E.; Pirelli, G.J. Organic and inorganic selenium: I. Oral bioavailability in ewes. J. Anim. Sci. 2012, 90, 568-576. [CrossRef] [PubMed]

70. Galbraith, M.L.; Vorachek, W.R.; Estill, C.T.; Whanger, P.D.; Bobe, G.; Davis, T.Z.; Hall, J.A. Rumen Microorganisms Decrease Bioavailability of Inorganic Selenium Supplements. Biol. Trace Elem. Res. 2016, 171, 338-343. [CrossRef] [PubMed]

71. Kumar, N.; Garg, A.K.; Dass, R.S.; Chaturvedi, V.K.; Mudgal, V.; Varshney, V.P. Selenium supplementation influences growth performance, antioxidant status and immune response in lambs. Anim. Feed Sci. Technol. 2009, 153, 77-87. [CrossRef]

72. Juniper, D.T.; Phipps, R.H.; Givens, D.I.; Jones, A.K.; Green, C.; Bertin, G. Tolerance of ruminant animals to high dose in-feed administration of a selenium-enriched yeast1. J. Anim. Sci. 2008, 86, 197-204. [CrossRef] [PubMed]

73. Surai, P. Selenium in poultry nutrition 1. Antioxidant properties, deficiency and toxicity. World's Poult. Sci. J. 2002, 58, 333-347. [CrossRef]

74. Faixová, Z.; Piešová, E.; Maková, Z.; Čobanová, K.; Faix, Š. Effect of dietary supplementation with selenium-enriched yeast or sodium selenite on ruminal enzyme activities and blood chemistry in sheep. Acta Vet. Brno 2016, 85, 185-194. [CrossRef]

75. Pavlata, L.; Misurova, L.; Pechova, A.; Dvorak, R. The effect of inorganic and organically bound forms of selenium on glutathione peroxidase activity in the blood of goats. Vet. Med. 2011, 56, 75-81. [CrossRef]

76. Koenig, K.M.; Rode, L.M.; Cohen, R.D.; Buckley, W.T. Effects of diet and chemical form of selenium on selenium metabolism in sheep. J. Anim. Sci. 1997, 75, 817-827. [CrossRef] [PubMed]

77. Heindl, J.; Ledvinka, Z.; Englmaierová, M.; Zita, L.; Tumová, E. The effect of dietary selenium sources and levels on performance, selenium content in muscle and glutathione peroxidase activity in broiler chickens. Czech J. Anim. Sci. 2010, 55, 572-578. [CrossRef]

78. Wang, Z.-N.; Li, H.; Tang, H.; Zhang, S.-J.; Pauline, M.; Bi, C.-L. Short Communication: Effects of Dietary Selenium Supplementation on Selenium Deposition and Antioxidant Status in Postpartum Mice. Biol. Trace Elem. Res. 2021, 199, $1488-1492$. [CrossRef]

79. Novoselec, J.; Šperanda, M.; Klir, Ž.; Mioč, B.; Steiner, Z.; Antunović, Z. Blood biochemical indicators and concentration of thyroid hormones in heavily pregnant and lactating ewes depending on selenium supplementation. Acta Vet. Brno 2018, 86, 353-363. [CrossRef]

80. Ortman, K.; Pehrson, B. Effect of selenate as a feed supplement to dairy cows in comparison to selenite and selenium yeast. J. Anim. Sci. 1999, 77, 3365-3370. [CrossRef]

81. Petrera, F.; Calamari, L.; Bertin, G. Effect of either sodium selenite or Se-yeast supplementation on selenium status and milk characteristics in dairy goats. Small Rumin. Res. 2009, 82, 130-138. [CrossRef]

82. Kachuee, R.; Abdi-Benemar, H.; Mansoori, Y.; Sánchez-Aparicio, P.; Seifdavati, J.; Elghandour, M.M.M.Y.; Guillén, R.J.; Salem, A.Z.M. Effects of Sodium Selenite, L-Selenomethionine, and Selenium Nanoparticles during Late Pregnancy on Selenium, Zinc, Copper, and Iron Concentrations in Khalkhali Goats and Their Kids. Biol. Trace Elem. Res. 2019, 191, 389-402. [CrossRef] [PubMed]

83. Kouba, A.; Velíšek, J.; Stará, A.; Masojídek, J.; Kozák, P. Supplementation with sodium selenite and selenium-enriched microalgae biomass show varying effects on blood enzymes activities, antioxidant response, and accumulation in common barbel (Barbus barbus). BioMed Res. Int. 2014, 2014, 408270. [CrossRef] [PubMed]

84. Doucha, J.; Lívanský, K.; Kotrbácek, V.; Zachleder, V. Production of Chlorella biomass enriched by selenium and its use in animal nutrition: A review. Appl. Microbiol. Biotechnol. 2009, 83, 1001-1008. [CrossRef]

85. Marounek, M.; Dokoupilová, A.; Volek, Z.; Hoza, I. Quality of meat and selenium content in tissues of rabbits fed diets supplemented with sodium selenite, selenized yeast and selenized algae. World Rabbit Sci. 2009, 17, 207-212. [CrossRef] 
86. Hassan, F.A.; Abdel-Azeem, N.; Abdel-Rahman, S.; Amin, H.F.; Abdel-Mawla, L.F. Effect of Dietary Organic Selenium Supplementation yfon Growth Performance, Carcass Characteristics and Antioxidative Status of Growing Rabbits. World Vet. J. 2019, 9, 16-25. Available online: www.wvj.science-line.com (accessed on 3 November 2021).

87. Amer, F.; Hoballah, E.; Basyony, M.; El-Medany, S. Effect of dietary selenium enriched micro-algae supplementation on growth performance and anti-oxidative status of rabbits under high ambient temperature in summer season. Egypt. J. Nutr. Feeds 2015, 18, 229-244. [CrossRef]

88. De Alcantara, S.; Lopes, C.C.; Wagener, K. Controlled introduction of selenium into Chlorella cells. Indian J. Exp. Biol. 1998, 36, 1286-1288.

89. Neumann, P.M.; De Souza, M.P.; Pickering, I.J.; Terry, N. Rapid microalgal metabolism of selenate to volatile dimethylselenide. Plant Cell Environ. 2003, 26, 897-905. [CrossRef]

90. Brummer, F.A.; Perelli, F.J.; Hall, J.A. Selenium Supplementation Strategies for Livestock in Oregon. 2014. Available online: https:/ / catalog.extension.oregonstate.edu/sites/catalog/files/project/pdf/em9094.pdf (accessed on 3 November 2021).

91. Smith, K.L.; Harrison, J.H.; Hancock, D.D.; Todhunter, D.A.; Conrad, H.R. Effect of vitamin E and selenium supplementation on incidence of clinical mastitis and duration of clinical symptoms. J. Dairy Sci. 1984, 67, 1293-1300. [CrossRef]

92. Zahrazadeh, M.; Riasi, A.; Farhangfar, H.; Mahyari, S.A. Effects of close-up body condition score and selenium-vitamin E injection on lactation performance, blood metabolites, and oxidative status in high-producing dairy cows. J. Dairy Sci. 2018, 101, 10495-10504. [CrossRef] [PubMed]

93. Hogan, J.S.; Weiss, W.P.; Smith, K.L. Role of vitamin E and selenium in host defense against mastitis. J. Dairy Sci. 1993, 76, 2795-2803. [CrossRef]

94. Talib, A.; Bomboi, G.; Basilio, F. Does Vitamin E or Vitamin E plus Selenium improve reproductive performance of rams during hot weather? Ital. J. Anim. Sci. 2010, 8, 743-754. [CrossRef]

95. Marin-Guzman, J.; Mahan, D.C.; Chung, Y.K.; Pate, J.L.; Pope, W.F. Effects of dietary selenium and vitamin E on boar performance and tissue responses, semen quality, and subsequent fertilization rates in mature gilts. J. Anim. Sci. 1997, 75, 2994-3003. [CrossRef]

96. Kappel, L.C.; Ingraham, R.H.; Morgan, E.B.; Dixon, J.M.; Zeringue, L.; Wilson, D.; Babcock, D.K. Selenium concentrations in feeds and effects of treating pregnant Holstein cows with selenium and vitamin $\mathrm{E}$ on blood selenium values and reproductive performance. Am. J. Vet. Res. 1984, 45, 691-694.

97. Dalia, A.M.; Loh, T.C.; Sazili, A.Q.; Jahromi, M.F.; Samsudin, A.A. Effects of vitamin E, inorganic selenium, bacterial organic selenium, and their combinations on immunity response in broiler chickens. BMC Vet. Res. 2018, 14, 249. [CrossRef]

98. El-Hak, H.N.G.; Elaraby, E.E.; Hassan, A.K.; Abbas, O.A. Study of the toxic effect and safety of vitamin E supplement in male albino rats after 30 days of repeated treatment. Heliyon 2019, 5, e02645. [CrossRef]

99. Hale, T.W.; Rais-Bahrami, K.; Montgomery, D.L.; Harkey, C.; Habersang, R.W. Vitamin E Toxicity in Neonatal Piglets. J. Toxicol. Clin. Toxicol. 1995, 33, 123-130. [CrossRef]

100. Horky, P.; Ruttkay-Nedecky, B.; Nejdl, L.; Richtera, L.; Cernei, N.; Pohanka, M.; Kopel, P.; Skladanka, J.; Hloucalova, P.; Slama, P.; et al. Electrochemical Methods for Study of Influence of Selenium Nanoparticles on Antioxidant Status of Rats. Int. J. Electrochem. Sci. 2016, 11, 2799-2824. [CrossRef]

101. Fratoddi, I. Hydrophobic and Hydrophilic Au and Ag Nanoparticles. Breakthroughs and Perspectives. Nanomaterials 2017, 8, 11. [CrossRef] [PubMed]

102. Desai, M.P.; Labhasetwar, V.; Walter, E.; Levy, R.J.; Amidon, G.L. The mechanism of uptake of biodegradable microparticles in Caco-2 cells is size dependent. Pharm. Res. 1997, 14, 1568-1573. [CrossRef] [PubMed]

103. Corbo, C.; Molinaro, R.; Parodi, A.; Toledano Furman, N.E.; Salvatore, F.; Tasciotti, E. The impact of nanoparticle protein corona on cytotoxicity, immunotoxicity and target drug delivery. Nanomedicine (Lond.) 2016, 11, 81-100. [CrossRef]

104. Abdelnour, S.; Alagawany, M.; Hashem, N.; Farag, M.; Alghamdi, E.; Hassan, F.-u.; Bilal, R.; Elnesr, S.; Dawood, M.; Nagadi, S.; et al. Nanominerals: Fabrication Methods, Benefits and Hazards, and Their Applications in Ruminants with Special Reference to Selenium and Zinc Nanoparticles. Animals 2021, 11, 1916. [CrossRef]

105. Trang, H.D.N. Antibacterial properties of selenium nanoparticles and their toxicity to Caco-2 cells. Food Control 2017, 77, 17-24 [CrossRef]

106. Shakibaie, M.; Forootanfar, H.; Golkari, Y.; Mohammadi-Khorsand, T.; Shakibaie, M.R. Anti-biofilm activity of biogenic selenium nanoparticles and selenium dioxide against clinical isolates of Staphylococcus aureus, Pseudomonas aeruginosa, and Proteus mirabilis. J. Trace Elem. Med. Biol. 2015, 29, 235-241. [CrossRef]

107. Keyhani, A.; Zia-ali, N.; Shakibaie, M.; Kareshk, A.; Shojaee, S.; Asadi-Shekaari, M.; Sepahvand, M.; Mahmoudvand, H. Biogenic selenium nanoparticles target chronic toxoplasmosis with minimal cytotoxicity in a mouse model. J. Med. Microbiol. 2019, 69. [CrossRef] [PubMed]

108. El-Zayat, M.M.; Eraqi, M.M.; Alrefai, H.; El-Khateeb, A.Y.; Ibrahim, M.A.; Aljohani, H.M.; Aljohani, M.M.; Elshaer, M.M. The Antimicrobial, Antioxidant, and Anticancer Activity of Greenly Synthesized Selenium and Zinc Composite Nanoparticles Using Ephedra aphylla Extract. Biomolecules 2021, 11, 470. [CrossRef] [PubMed]

109. Lv, Q.; Liang, X.; Nong, K.; Gong, Z.; Qin, T.; Qin, X.; Wang, D.; Zhu, Y. Advances in Research on the Toxicological Effects of Selenium. Bull. Environ. Contam. Toxicol. 2021, 106, 715-726. [CrossRef]

110. Baig, N.; Kammakakam, I.; Falath, W.S. Nanomaterials: A review of synthesis, properties, recent progress, and challenges. Mater. Adv. 2021, 2, 1821-1871. [CrossRef] 
111. Sabella, S.; Carney, R.P.; Brunetti, V.; Malvindi, M.A.; Al-Juffali, N.; Vecchio, G.; Janes, S.M.; Bakr, O.M.; Cingolani, R.; Stellacci, F.; et al. A general mechanism for intracellular toxicity of metal-containing nanoparticles. Nanoscale 2014, 6, 7052-7061. [CrossRef] [PubMed]

112. Ramanathan, A. Toxicity of nanoparticles_challenges and opportunities. Appl. Microsc. 2019, 49, 2. [CrossRef]

113. Maharramov, A.M.; Hasanova, U.A.; Suleymanova, I.A.; Osmanova, G.E.; Hajiyeva, N.E. The engineered nanoparticles in food chain: Potential toxicity and effects. SN Appl. Sci. 2019, 1, 1362. [CrossRef]

114. Elhardallou, S.; Babiker, W.; Sulieman, A.M.; Gobouri, A. Effect of Diet Supplementation with Food Industry By-Products on Diabetic Rats. Food Nutr. Sci. 2015, 6, 875-882. [CrossRef]

115. Boudreau, M.D.; Imam, M.S.; Paredes, A.M.; Bryant, M.S.; Cunningham, C.K.; Felton, R.P.; Jones, M.Y.; Davis, K.J.; Olson, G.R Differential Effects of Silver Nanoparticles and Silver Ions on Tissue Accumulation, Distribution, and Toxicity in the Sprague Dawley Rat Following Daily Oral Gavage Administration for 13 Weeks. Toxicol. Sci. 2016, 150, 131-160. [CrossRef]

116. Khan, F.H. Chemical hazards of nanoparticles to human and environment (a review). Orient. J. Chem. 2013, 29, 1399. [CrossRef]

117. Buchman, J.T.; Hudson-Smith, N.V.; Landy, K.M.; Haynes, C.L. Understanding Nanoparticle Toxicity Mechanisms To Inform Redesign Strategies To Reduce Environmental Impact. Acc. Chem. Res. 2019, 52, 1632-1642. [CrossRef]

118. Shi, L.; Xun, W.; Yue, W.; Zhang, C.; Ren, Y.; Qiang, L.; Wang, Q.; Shi, L. Effect of elemental nano-selenium on feed digestibility, rumen fermentation, and purine derivatives in sheep. Fuel Energy Abstr. 2011, 163, 136-142. [CrossRef]

119. Kojouri, G.; Arbabi, F.; Mohebbi, A. The effects of selenium nanoparticles (SeNPs) on oxidant and antioxidant activities and neonatal lamb weight gain pattern. Comp. Clin. Pathol. 2020, 29, 369-374. [CrossRef]

120. Sadeghian, S.; Kojouri, G.A.; Mohebbi, A. Nanoparticles of selenium as species with stronger physiological effects in sheep in comparison with sodium selenite. Biol. Trace Elem. Res. 2012, 146, 302-308. [CrossRef]

121. Xun, W.; Shi, L.; Yue, W.; Zhang, C.; Ren, Y.; Qiang, L. Effect of High-Dose Nano-selenium and Selenium-Yeast on Feed Digestibility, Rumen Fermentation, and Purine Derivatives in Sheep. Biol. Trace Elem. Res. 2012, 150, 130-136. [CrossRef] [PubMed]

122. Wu, X.; Yao, J.; Yang, Z.; Yue, W.; Ren, Y.; Zhang, C.; Liu, X.; Wang, H.; Zhao, X.; Yuan, S.; et al. Improved fetal hair follicle development by maternal supplement of selenium at nano size (Nano-Se). Livest. Sci. 2011, 142, 270-275. [CrossRef]

123. Gangadoo, S.; Dinev, I.; Chapman, J.; Hughes, R.J.; Van, T.T.H.; Moore, R.J.; Stanley, D. Selenium nanoparticles in poultry feed modify gut microbiota and increase abundance of Faecalibacterium prausnitzii. Appl. Microbiol. Biotechnol. 2018, 102, 1455-1466. [CrossRef]

124. Wang, Y. Differential effects of sodium selenite and nano-Se on growth performance, tissue se distribution, and glutathione peroxidase activity of avian broiler. Biol. Trace Elem. Res. 2009, 128, 184-190. [CrossRef]

125. Gulyas, G.; Csosz, E.; Prokisch, J.; Javor, A.; Mezes, M.; Erdelyi, M.; Balogh, K.; Janaky, T.; Szabo, Z.; Simon, A.; et al. Effect of nano-sized, elemental selenium supplement on the proteome of chicken liver. J. Anim. Physiol. Anim. Nutr. (Berl.) 2017, 101, 502-510. [CrossRef]

126. Kohshahi, A.J.; Sourinejad, I.; Sarkheil, M.; Johari, S.A. Dietary cosupplementation with curcumin and different selenium sources (nanoparticulate, organic, and inorganic selenium): Influence on growth performance, body composition, immune responses, and glutathione peroxidase activity of rainbow trout (Oncorhynchus mykiss). Fish Physiol. Biochem. 2019, 45, 793-804.

127. Jahanbakhshi, A.; Pourmozaffar, S.; Adeshina, I.; Mahmoudi, R.; Erfanifar, E.; Ajdari, A. Selenium nanoparticle and selenomethionine as feed additives: Effects on growth performance, hepatic enzymes' activity, mucosal immune parameters, liver histology, and appetite-related gene transcript in goldfish (Carassius auratus). Fish Physiol. Biochem. 2021, 47, 639-652. [CrossRef]

128. Liu, G.; Yu, H.; Wang, C.; Li, P.; Liu, S.; Zhang, X.; Zhang, C.; Qi, M.; Ji, H. Nano-selenium supplements in high-fat diets relieve hepatopancreas injury and improve survival of grass carp Ctenopharyngodon Idella by reducing lipid deposition. Aquaculture 2021, 538, 736580. [CrossRef]

129. Dawood, M.A. Nutritional immunity of fish intestines: Important insights for sustainable aquaculture. Rev. Aquac. 2021, 13, 642-663. [CrossRef]

130. Ghazi, S.; Diab, A.M.; Khalafalla, M.M.; Mohamed, R.A. Synergistic Effects of Selenium and Zinc Oxide Nanoparticles on Growth Performance, Hemato-biochemical Profile, Immune and Oxidative Stress Responses, and Intestinal Morphometry of Nile Tilapia (Oreochromis niloticus). Biol. Trace Elem. Res. 2021, 200, 364-374. [CrossRef]

131. Longbaf Dezfouli, M.; Ghaedtaheri, A.; Keyvanshokooh, S.; Salati, A.P.; Mousavi, S.M.; Pasha-Zanoosi, H. Combined or individual effects of dietary magnesium and selenium nanoparticles on growth performance, immunity, blood biochemistry and antioxidant status of Asian seabass (Lates calcarifer) reared in freshwater. Aquac. Nutr. 2019, 25, 1422-1430. [CrossRef]

132. Zhang, T.; Yao, C.; Hu, Z.; Li, D.; Tang, R. Protective Effect of Selenium on the Oxidative Damage of Kidney Cells Induced by Sodium Nitrite in Grass Carp (Ctenopharyngodon idellus). Biol. Trace Elem. Res. 2021. [CrossRef] [PubMed]

133. Ibrahim, M.S.; El-gendy, G.M.; Ahmed, A.I.; Elharoun, E.R.; Hassaan, M.S. Nanoselenium versus bulk selenium as a dietary supplement: Effects on growth, feed efficiency, intestinal histology, haemato-biochemical and oxidative stress biomarkers in Nile tilapia (Oreochromis niloticus Linnaeus, 1758) fingerlings. Aquac. Res. 2021, 52, 5642-5655. [CrossRef]

134. Dawood, M.A.O.; Basuini, M.F.E.; Yilmaz, S.; Abdel-Latif, H.M.R.; Kari, Z.A.; Abdul Razab, M.K.A.; Ahmed, H.A.; Alagawany, M.; Gewaily, M.S. Selenium Nanoparticles as a Natural Antioxidant and Metabolic Regulator in Aquaculture: A Review. Antioxidants 2021, 10, 1364. [CrossRef] [PubMed] 
135. Yaghmaie, P.; Ramin, A.; Asri-Rezaei, S.; Zamani, A. Evaluation of glutathion peroxidase activity, trace minerals and weight gain following administration of selenium compounds in lambs. Vet. Res. Forum 2017, 8, 133-137.

136. Urbankova, L.; Skalickova, S.; Pribilova, M.; Ridoskova, A.; Pelcova, P.; Skladanka, J.; Horky, P. Effects of Sub-Lethal Doses of Selenium Nanoparticles on the Health Status of Rats. Toxics 2021, 9, 28. [CrossRef] [PubMed]

137. Benko, I.; Nagy, G.; Tanczos, B.; Ungvari, E.; Sztrik, A.; Eszenyi, P.; Prokisch, J.; Banfalvi, G. Subacute toxicity of nano-selenium compared to other selenium species in mice. Environ. Toxicol. Chem. 2012, 31, 2812-2820. [CrossRef]

138. He, Y.; Chen, S.; Liu, Z.; Cheng, C.; Li, H.; Wang, M. Toxicity of selenium nanoparticles in male Sprague-Dawley rats at supranutritional and nonlethal levels. Life Sci. 2014, 115, 44-51. [CrossRef] [PubMed]

139. Liu, L.; He, Y.; Xiao, Z.; Tao, W.; Zhu, J.; Wang, B.; Liu, Z.; Wang, M. Effects of Selenium Nanoparticles on Reproductive Performance of Male Sprague-Dawley Rats at Supranutritional and Nonlethal Levels. Biol. Trace Elem. Res. 2017, 180, 81-89. [CrossRef]

140. Jin, Y.; He, Y.; Liu, L.; Tao, W.; Wang, G.; Sun, W.; Pei, X.; Xiao, Z.; Wang, H.; Wang, M. Effects of Supranutritional Selenium Nanoparticles on Immune and Antioxidant Capacity in Sprague-Dawley Rats. Biol. Trace Elem. Res. 2021, 199, 4666-4674. [CrossRef] [PubMed]

141. Wang, H.; He, Y.; Liu, L.; Tao, W.; Wang, G.; Sun, W.; Pei, X.; Xiao, Z.; Jin, Y.; Wang, M. Prooxidation and Cytotoxicity of Selenium Nanoparticles at Nonlethal Level in Sprague-Dawley Rats and Buffalo Rat Liver Cells. Oxid. Med. Cell. Longev. 2020, 2020, 7680276. [CrossRef]

142. Hadrup, N.; Loeschner, K.; Mandrup, K.; Ravn-Haren, G.; Frandsen, H.L.; Larsen, E.H.; Lam, H.R.; Mortensen, A. Subacute oral toxicity investigation of selenium nanoparticles and selenite in rats. Drug Chem. Toxicol. 2019, 42, 76-83. [CrossRef] [PubMed]

143. Qamar, N.; John, P.; Bhatti, A. Toxicological and Anti-Rheumatic Potential of Trachyspermum ammi Derived Biogenic Selenium Nanoparticles in Arthritic Balb/c Mice. Int. J. Nanomed. 2020, 15, 3497-3509. [CrossRef]

144. Qiao, L.; Dou, X.; Yan, S.; Zhang, B.; Xu, C. Biogenic selenium nanoparticles by Lactobacillus casei ATCC 393 alleviate diquatinduced intestinal barrier dysfunction in C57BL/6 mice through their antioxidant activity. Food Funct. 2020, 11, 3020-3031. [CrossRef]

145. Song, X.; Qiao, L.; Yan, S.; Chen, Y.; Dou, X.; Xu, C. Preparation, characterization, and in vivo evaluation of anti-inflammatory activities of selenium nanoparticles synthesized by Kluyveromyces lactis GG799. Food Funct. 2021, 12, 6403-6415. [CrossRef]

146. Cai, S.J.; Wu, C.X.; Gong, L.M.; Song, T.; Wu, H.; Zhang, L.Y. Effects of nano-selenium on performance, meat quality, immune function, oxidation resistance, and tissue selenium content in broilers. Poult. Sci. 2012, 91, 2532-2539. [CrossRef]

147. El-Deep, M.; Ijiri, D.; Ebeid, T.; Ohtsuka, A. Effects of Dietary Nano-Selenium Supplementation on Growth Performance, Antioxidative Status, and Immunity in Broiler Chickens under Thermoneutral and High Ambient Temperature Conditions. J. Poult. Sci. 2016, 53. [CrossRef]

148. Ahmadi, M.; Ahmadian, A.; Seidavi, A. Effect of Different Levels of Nano-selenium on Performance, Blood Parameters, Immunity and Carcass Characteristics of BroilerChickens. Poult. Sci. J. 2018, 6, 99-108. [CrossRef]

149. Bakhshalinejad, R.; Akbari Moghaddam Kakhki, R.; Zoidis, E. Effects of different dietary sources and levels of selenium supplements on growth performance, antioxidant status and immune parameters in Ross 308 broiler chickens. Br. Poult. Sci. 2018, 59, 81-91. [CrossRef]

150. Ibrahim, D.; Kishawy, A.T.Y.; Khater, S.I.; Hamed Arisha, A.; Mohammed, H.A.; Abdelaziz, A.S.; Abd El-Rahman, G.I.; Elabbasy, M.T. Effect of Dietary Modulation of Selenium Form and Level on Performance, Tissue Retention, Quality of Frozen Stored Meat and Gene Expression of Antioxidant Status in Ross Broiler Chickens. Animals 2019, 9, 342. [CrossRef]

151. Shabani, R.; Fakhraei, J.; Yarahmadi, H.; Seidavi, A. Effect of different sources of selenium on performance and characteristics of immune system of broiler chickens. Rev. Bras. Zootec. 2019, 48. [CrossRef]

152. Popescu, M.; Velea, A.; Lőrinczi, A. Biogenic production of nanoparticles. Dig. J. Nanomater. Biostruct. 2010, 5, $1035-1040$.

153. Wadhwani, S.A.; Shedbalkar, U.U.; Singh, R.; Chopade, B.A. Biogenic selenium nanoparticles: Current status and future prospects. Appl. Microbiol. Biotechnol. 2016, 100, 2555-2566. [CrossRef]

154. Kumar, N.; Krishnani, K.K.; Singh, N.P. Comparative study of selenium and selenium nanoparticles with reference to acute toxicity, biochemical attributes, and histopathological response in fish. Environ. Sci. Pollut. Res. 2018, 25, 8914-8927. [CrossRef]

155. Li, H.; Zhang, J.; Wang, T.; Luo, W.; Zhou, Q.; Jiang, G. Elemental selenium particles at nano-size (Nano-Se) are more toxic to Medaka (Oryzias latipes) as a consequence of hyper-accumulation of selenium: A comparison with sodium selenite. Aquat. Toxicol. 2008, 89, 251-256. [CrossRef]

156. Hassanin, K.M.; Abd El-Kawi, S.H.; Hashem, K.S. The prospective protective effect of selenium nanoparticles against chromiuminduced oxidative and cellular damage in rat thyroid. Int. J. Nanomed. 2013, 8, 1713-1720. [CrossRef]

157. Zhou, X.; Wang, Y.; Gu, Q.; Li, W. Effect of different dietary selenium source (selenium nanoparticle and selenomethionine) on growth performance, muscle composition and glutathione peroxidase enzyme activity of crucian carp (Carassius auratus gibelio). Aquaculture 2009, 291, 78-81. [CrossRef]

158. Sharma, D.; Kanchi, S.; Bisetty, K. Biogenic synthesis of nanoparticles: A review. Arab. J. Chem. 2019, 12, 3576-3600. [CrossRef]

159. Duan, H.; Wang, D.; Li, Y. Green Chemistry for Nanoparticle Synthesis. Chem. Soc. Rev. 2015, 44, 5778-5792. [CrossRef] [PubMed]

160. Al-khattaf, F.S. Gold and silver nanoparticles: Green synthesis, microbes, mechanism, factors, plant disease management and environmental risks. Saudi J. Biol. Sci. 2021, 28, 3624-3631. [CrossRef] [PubMed] 
161. Javed, R.; Zia, M.; Naz, S.; Aisida, S.O.; Ain, N.u.; Ao, Q. Role of capping agents in the application of nanoparticles in biomedicine and environmental remediation: Recent trends and future prospects. J. Nanobiotechnol. 2020, 18, 172. [CrossRef]

162. Iravani, S.; Korbekandi, H.; Mirmohammadi, S.V.; Zolfaghari, B. Synthesis of silver nanoparticles: Chemical, physical and biological methods. Res. Pharm. Sci. 2014, 9, 385-406.

163. Bhattarai, B.; Zaker, Y.; Bigioni, T.P. Green synthesis of gold and silver nanoparticles: Challenges and opportunities. Curr. Opin. Green Sustain. Chem. 2018, 12, 91-100. [CrossRef]

164. Cardoso-Avila, P.E.; Patakfalvi, R.; Rodríguez-Pedroza, C.; Aparicio-Fernández, X.; Loza-Cornejo, S.; Villa-Cruz, V.; MartínezCano, E. One-pot green synthesis of gold and silver nanoparticles using Rosa canina L. extract. RSC Adv. 2021, 11, 14624-14631. [CrossRef]

165. Hosny, M.; Fawzy, M.; Abdelfatah, A.M.; Fawzy, E.E.; Eltaweil, A.S. Comparative study on the potentialities of two halophytic species in the green synthesis of gold nanoparticles and their anticancer, antioxidant and catalytic efficiencies. Adv. Powder Technol. 2021, 32, 3220-3233. [CrossRef]

166. Muthusamy, A.; Pottail, L. Rapid Green Synthesis of Gold and Silver Nanoparticles Using Ethanol Extract of Kedrostis Foetidissima (JACQ) COGN. And Its Anticancer Efficacy against A549 Human Lung Cancer Cell Lines. Indian Drugs 2021, 58, 30-40. Available online: http:/ / www.indiandrugsonline.org/issuesarticle-details?id=MTE1OQ (accessed on 3 November 2021).

167. Anu, K.; Singaravelu, G.; Murugan, K.; Benelli, G. Green-Synthesis of Selenium Nanoparticles Using Garlic Cloves (Allium sativum): Biophysical Characterization and Cytotoxicity on Vero Cells. J. Clust. Sci. 2017, 28, 551-563. [CrossRef]

168. Kokila, K.; Elavarasan, N.; Sujatha, V. Diospyros montana leaf extract-mediated synthesis of selenium nanoparticles and their biological applications. New J. Chem. 2017, 41, 7481-7490. [CrossRef]

169. Zhang, W.; Zhang, J.; Ding, D.; Zhang, L.; Muehlmann, L.A.; Deng, S.-e.; Wang, X.; Li, W.; Zhang, W. Synthesis and antioxidant properties of Lycium barbarum polysaccharides capped selenium nanoparticles using tea extract. Artif. Cells Nanomed. Biotechnol. 2018, 46, 1463-1470. [CrossRef]

170. Salem, S.S.; Fouda, M.M.; Fouda, A.; Awad, M.A.; Al-Olayan, E.M.; Allam, A.A.; Shaheen, T.I. Antibacterial, cytotoxicity and larvicidal activity of green synthesized selenium nanoparticles using Penicillium corylophilum. J. Clust. Sci. 2021, 32, $351-361$. [CrossRef]

171. Regulation (EC) No 1831/2003 of the European Parliament and of the Council of 22 September 2003 on Additives for Use in Animal Nutrition. 2003. Available online: https://eur-lex.europa.eu/legal-content/EN/TXT/?uri=CELEX\%3A32003R1831 (accessed on 3 November 2021).

172. Ramesh, M.; Anbuvannan, M.; Viruthagiri, G. Green synthesis of ZnO nanoparticles using Solanum nigrum leaf extract and their antibacterial activity. Spectrochim. Acta Part A Mol. Biomol. Spectrosc. 2015, 136, 864-870. [CrossRef]

173. Agarwal, H.; Venkat Kumar, S.; Rajeshkumar, S. A review on green synthesis of zinc oxide nanoparticles-An eco-friendly approach. Resour.-Effic. Technol. 2017, 3, 406-413. [CrossRef]

174. Horky, P.; Skalickova, S.; Urbankova, L.; Baholet, D.; Kociova, S.; Bytesnikova, Z.; Kabourkova, E.; Lackova, Z.; Cernei, N.; Gagic, M. Zinc phosphate-based nanoparticles as a novel antibacterial agent: In vivo study on rats after dietary exposure. J. Anim. Sci. Biotechnol. 2019, 10, 1-12. [CrossRef] [PubMed]

175. Cremonini, E.; Zonaro, E.; Donini, M.; Lampis, S.; Boaretti, M.; Dusi, S.; Melotti, P.; Lleo, M.M.; Vallini, G. Biogenic selenium nanoparticles: Characterization, antimicrobial activity and effects on human dendritic cells and fibroblasts. Microb. Biotechnol. 2016, 9, 758-771. [CrossRef] [PubMed]

176. Pandey, S.; Awasthee, N.; Shekher, A.; Rai, L.C.; Gupta, S.C.; Dubey, S.K. Biogenic synthesis and characterization of selenium nanoparticles and their applications with special reference to antibacterial, antioxidant, anticancer and photocatalytic activity. Bioprocess Biosyst. Eng. 2021, 44, 2679-2696. [CrossRef]

177. Yan, S.; Qiao, L.; Dou, X.; fan Song, X.; Chen, Y.; Zhang, B.; Xu, C. Biogenic Selenium nanoparticles by Lactobacillus casei ATCC 393 alleviate the intestinal permeability, mitochondrial dysfunction and mitophagy induced by oxidative stress. Food Funct. 2021. [CrossRef]

178. Alvi, G.B.; Iqbal, M.S.; Ghaith, M.M.S.; Haseeb, A.; Ahmed, B.; Qadir, M.I. Biogenic selenium nanoparticles (SeNPs) from citrus fruit have anti-bacterial activities. Sci. Rep. 2021, 11, 1-11. [CrossRef]

179. Kanchi, S.; Khan, A. Biogenic Synthesis of Selenium Nanoparticles with Edible Mushroom Extract: Evaluation of Cytotoxicity on Prostate Cancer Cell Lines and Their Antioxidant, and Antibacterial Activity. Biointerface Res. Appl. Chem. 2020, 10, 6629-6639.

180. Vinu, D.; Govindaraju, K.; Vasantharaja, R.; Amreen Nisa, S.; Kannan, M.; Vijai Anand, K. Biogenic zinc oxide, copper oxide and selenium nanoparticles: Preparation, characterization and their anti-bacterial activity against Vibrio parahaemolyticus. J. Nanostruct. Chem. 2021, 11, 271-286. [CrossRef]

181. Sonkusre, P.; Cameotra, S.S. Biogenic selenium nanoparticles induce ROS-mediated necroptosis in PC-3 cancer cells through TNF activation. J. Nanobiotechnol. 2017, 15, 43. [CrossRef]

182. Lian, S.; Diko, C.S.; Yan, Y.; Li, Z.; Zhang, H.; Ma, Q.; Qu, Y. Characterization of biogenic selenium nanoparticles derived from cell-free extracts of a novel yeast Magnusiomyces ingens. 3 Biotech 2019, 9, 221. [CrossRef]

183. Hu, D.; Yu, S.; Yu, D.; Liu, N.; Tang, Y.; Fan, Y.; Wang, C.; Wu, A. Biogenic Trichoderma harzianum-derived selenium nanoparticles with control functionalities originating from diverse recognition metabolites against phytopathogens and mycotoxins. Food Control 2019, 106, 106748. [CrossRef] 
184. Menon, S.; Devi, S.; Agarwal, H.; Kumar, V. Efficacy of Biogenic Selenium Nanoparticles from an Extract of Ginger towards Evaluation on Anti-Microbial and Anti-Oxidant Activities. Colloid Interface Sci. Commun. 2019, 29, 1-8. [CrossRef]

185. Cittrarasu, V.; Kaliannan, D.; Dharman, K.; Maluventhen, V.; Easwaran, M.; Liu, W.C.; Balasubramanian, B.; Arumugam, M. Green synthesis of selenium nanoparticles mediated from Ceropegia bulbosa Roxb extract and its cytotoxicity, antimicrobial, mosquitocidal and photocatalytic activities. Sci. Rep. 2021, 11, 1032. [CrossRef]

186. Abbas, H.S.; Abou Baker, D.H.; Ahmed, E.A. Cytotoxicity and antimicrobial efficiency of selenium nanoparticles biosynthesized by Spirulina platensis. Arch. Microbiol. 2021, 203, 523-532. [CrossRef]

187. Medina Cruz, D.; Mi, G.; Webster, T.J. Synthesis and characterization of biogenic selenium nanoparticles with antimicrobial properties made by Staphylococcus aureus, methicillin-resistant Staphylococcus aureus (MRSA), Escherichia coli, and Pseudomonas aeruginosa. J. Biomed. Mater. Res. Part A 2018, 106, 1400-1412. [CrossRef] [PubMed]

188. Huang, T.; Holden, J.A.; Reynolds, E.C.; Heath, D.E.; O'Brien-Simpson, N.M.; O'Connor, A.J. Multifunctional Antimicrobial Polypeptide-Selenium Nanoparticles Combat Drug-Resistant Bacteria. ACS Appl. Mater. Interfaces 2020, 12, 55696-55709. [CrossRef]

189. Zheng, S.; Su, J.; Wang, L.; Yao, R.; Wang, D.; Deng, Y.; Wang, R.; Wang, G.; Rensing, C. Selenite reduction by the obligate aerobic bacterium Comamonas testosteroni S44 isolated from a metal-contaminated soil. BMC Microbiol. 2014, 14, 204. [CrossRef]

190. Ovais, M.; Khalil, A.T.; Ayaz, M.; Ahmad, I.; Nethi, S.K.; Mukherjee, S. Biosynthesis of Metal Nanoparticles via Microbial Enzymes: A Mechanistic Approach. Int. J. Mol. Sci. 2018, 19, 4100. [CrossRef]

191. Mellinas, C.; Jiménez, A.; Garrigós, M.D.C. Microwave-Assisted Green Synthesis and Antioxidant Activity of Selenium Nanoparticles Using Theobroma cacao L. Bean Shell Extract. Molecules 2019, 24, 4048. [CrossRef] [PubMed]

192. Fardsadegh, B.; Jafarizadeh, H. Aloe vera leaf extract mediated green synthesis of selenium nanoparticles and assessment of their In vitro antimicrobial activity against spoilage fungi and pathogenic bacteria strains. Green Process. Synth. 2019, 8, 399-407. [CrossRef]

193. Singh, R.; Sadasivam, M.; Rakkiyappan, C. Ginger (Zingiber officinale) root extract: A source of silver NANOPARTICLES and their application. Int. J. Bio-Eng. Sci. Technol. 2021, 2, 75-80.

194. Pyrzynska, K.; Sentkowska, A. Biosynthesis of selenium nanoparticles using plant extracts. J. Nanostruct. Chem. 2021. [CrossRef]

195. Singh, R.; Shedbalkar, U.U.; Wadhwani, S.A.; Chopade, B.A. Bacteriagenic silver nanoparticles: Synthesis, mechanism, and applications. Appl. Microbiol. Biotechnol. 2015, 99, 4579-4593. [CrossRef]

196. Yazhiniprabha, M.; Vaseeharan, B. In vitro and in vivo toxicity assessment of selenium nanoparticles with significant larvicidal and bacteriostatic properties. Mater. Sci. Eng. C 2019, 103, 109763. [CrossRef]

197. Pandiyan, I.; Sakthi, S.D.; Indiran, M.A.; Rathinavelu, P.K.; Rajeshkumar, S. Mediated Selenium Nanoparticles, Characterization and its Antimicrobial Activity-An In Vitro Study. Thymus Vulgaris 2021, 7, 3516-3521.

198. Eswayah, A.S.; Smith, T.J.; Gardiner, P.H. Microbial Transformations of Selenium Species of Relevance to Bioremediation. Appl. Environ. Microbiol. 2016, 82, 4848-4859. [CrossRef]

199. Xu, X.; Cheng, W.; Liu, X.; You, H.; Wu, G.; Ding, K.; Tu, X.; Yang, L.; Wang, Y.; Li, Y.; et al. Selenate Reduction and Selenium Enrichment of Tea by the Endophytic Herbaspirillum sp. Strain WT00C. Curr. Microbiol. 2020, 77, 588-601. [CrossRef] [PubMed]

200. Afzal, B.; Fatma, T. Selenium Nanoparticles: Green Synthesis and Exploitation. In Merging Technologies for Nanoparticle Manufacturing; Patel, J.K., Pathak, Y.V., Eds.; Springer: Cham, Switzerland, 2021.

201. El-Saadony, M.T.; Saad, A.M.; Najjar, A.A.; Alzahrani, S.O.; Alkhatib, F.M.; Shafi, M.E.; Selem, E.; Desoky, E.M.; Fouda, S.E.E.; El-Tahan, A.M.; et al. The use of biological selenium nanoparticles to suppress Triticum aestivum L. crown and root rot diseases induced by Fusarium species and improve yield under drought and heat stress. Saudi J. Biol. Sci. 2021, 28, 4461-4471. [CrossRef] [PubMed]

202. Sasidharan, S.; Balakrishnaraja, R. Comparison Studies on the Synthesis of Selenium Nanoparticles by Various Micro-organisms. Int. J. Pure Appl. Biosci. 2014, 2, 112-117.

203. Afzal, B.; Yasin, D.; Husain, S.; Zaki, A.; Srivastava, P.; Kumar, R.; Fatma, T. Screening of cyanobacterial strains for the selenium nanoparticles synthesis and their anti-oxidant activity. Biocatal. Agric. Biotechnol. 2019, 21, 101307. [CrossRef]

204. Hariharan, H.; Al-Harbi, N.; Karuppiah, P.; Rajaram, S.K. Microbial synthesis of selinium nanocomposite using Saccharomyces cerevisiae and its antimicrobial activity against pathogens causing nosocomial infection. Chalcogenide Lett. 2012, 9, 509-515.

205. Shirsat, S.; Kadam, A.; Mane, R.; Jadhav, V.; Zate, M.; Highly Cited Researcher, M.; Kim, K. Protective Role of Biogenic Selenium Nanoparticles in Immunological and Oxidative Stress Generated by Enrofloxacin in Broiler Chicken. Dalton Trans. 2016, 45. [CrossRef]

206. Hadrová, S.; Sedláková, K.; Krizova, L.; Malyugina, S. Alternative and Unconventional Feeds in Dairy Diets and Their Effect on Fatty Acid Profile and Health Properties of Milk Fat. Animals 2021, 11, 1817. [CrossRef]

207. Singaravelu, G.; Arockiamary, J.; Kumar, G.; Govindaraju, K. A novel extracellular synthesis of monodisperse gold nanoparticles using marine alga, Sargassum wightii Greville. Colloids Surf. B Biointerfaces 2007, 57, 97-101. [CrossRef]

208. Luangpipat, T.; Beattie, I.; Chisti, Y.; Haverkamp, R. Gold nanoparticles produced in a microalga. J. Nanopart. Res. 2011, 13, 6439-6445. [CrossRef]

209. Senapati, S.; Syed, A.; Moeez, S.; Kumar, A.; Ahmad, A. Intracellular synthesis of gold nanoparticles using alga Tetraselmis kochinensis. Mater. Lett. 2012, 79, 116-118. [CrossRef] 
210. Castro, L.; Blázquez, M.L.; Muñoz, J.A.; González, F.; Ballester, A. Biological synthesis of metallic nanoparticles using algae. IET Nanobiotechnol. 2013, 7, 109-116. [CrossRef]

211. ElSaied, B.; Diab, A.; Tayel, A.; Alghuthaymi, M.; Moussa, S. Potent antibacterial action of phycosynthesized selenium nanoparticles using Spirulina platensis extract. Green Process. Synth. 2021, 10, 49-60. [CrossRef]

212. Mansouri-Tehrani, H.A.; Keyhanfar, M.; Behbahani, M.; Dini, G. Synthesis and characterization of algae-coated selenium nanoparticles as a novel antibacterial agent against Vibrio harveyi, a Penaeus vannamei pathogen. Aquaculture 2021, 534, 736260. [CrossRef]

213. Venkatesan, J.; Anil, S.; Kim, S.-K.; Shim, M.S. Seaweed polysaccharide-based nanoparticles: Preparation and applications for drug delivery. Polymers 2016, 8, 30. [CrossRef]

214. Chaudhary, R.; Nawaz, K.; Khan, A.K.; Hano, C.; Abbasi, B.H.; Anjum, S. An Overview of the Algae-Mediated Biosynthesis of Nanoparticles and Their Biomedical Applications. Biomolecules 2020, 10, 1498. [CrossRef] 